\title{
A FEASIBILITY STUDY ON THE ADVANCED PERFORMANCE INDICATOR CONCEPT FOR IMPROVING KINS SAFETY PERFORMANCE INDICATORS (SPI)
}

\author{
YONG SUK LEE ${ }^{* a}$, NAM CHUL $\mathrm{CHO}^{\mathrm{b}}$, and DAE WOOK CHUNG ${ }^{\mathrm{b}}$ \\ ${ }^{a}$ Future and Challenges Co \\ San 56-1 Sillim Dong, Kwanak Gu, Seoul, Korea 151-742 \\ ${ }^{\mathrm{b}}$ Korea Institute of Nuclear Safety \\ 19 Guseong Dong Yusong Gu, Daejeon, Korea 305-338 \\ *Corresponding author. E-mail : ys028@fnctech.com
}

Received February 17, 2010

Accepted for Publication December 01, 2010

The concept of improved performance indicators (PIs) for use in the KINS Safety Performance Indicator (SPI) program for reactor safety area is proposed in this paper. To achieve this, the recently developed PIs from the USNRC that use risk information were investigated, and a feasibility study for the application of these PIs in Korean NPPs was performed. The investigated PIs are Baseline Risk Index for Initiating Events (BRIIE), Unplanned Scrams with Complications (USwC), and Mitigating System Performance Index (MSPI). Moreover, the thresholds of the existing safety performance indicators of KINS were evaluated in consideration of the risk and regulatory response to different levels of licensee performance in the graded inspection program.

KEYWORDS : Performance Indicator Thresholds, Graded Inspection Program, Baseline Risk Index for Initiating Events, Unplanned Scrams with Complications, Mitigating System Performance Index, Barrier Integrity, Probabilistic Safety Assessment

\section{INTRODUCTION}

Many nuclear regulatory bodies across the world have developed PIs to objectively monitor the safety performance of nuclear power plants (NPPs), to enhance public confidence, and to perform regulatory evaluations (e.g. graded inspections) or decision processes [1]. Recently, some important PIs that use risk information have been developed and implemented for risk-informed regulatory oversight of NPPs in USNRC [2].

The safety performance indicator (SPI) system was introduced in Korea Institute of Nuclear Safety (KINS), which has been the nuclear regulatory expert organization in Korea since in 1995 [3]. The SPI system is used to monitor plant safety to investigate systems detrimental to reactor safety in order to enhance public confidence in the NPP operational safety and to follow the international trend in PIs. The SPI system is color coded by four levels (Green, Cyan, Yellow, Orange) as presented in Table 1, which is similar to the reactor oversight process (ROP) PIs from the USNRC. In the USNRC, the ROP PI system is used to determine the safety grade of each NPP and to determine if the inspection items and resources are increased or decreased depending on the safety grade (i.e. graded inspection) [4]. However, the SPI system in KINS has not been used in formal regulatory decision processes similar to the ROP of the USNRC because the existing regulatory inspection program does not include a graded approach based on the safety grade of each NPP.

KINS is developing the Integrated Safety Performance Assessment (ISPA) program to improve the existing regulatory inspection system using the results of the PSA and safety performance assessment [5]. In the ISPA program, graded inspection will be implemented and PIs will be a primary component in determining the safety grade of each NPP. Therefore, it has become important to enhance the existing SPI system for use in the graded inspection program in KINS.

In light of these circumstances, a feasibility study of some PIs that use risk information in the USNRC [7] was undertaken. In the USNRC, the Mitigating System Performance Index (MSPI) [6] was developed to monitor the mitigating system unreliability and unavailability at the plant level using probabilistic safety assessment (PSA) results for NPPs, and has been used since 2006. The Unplanned Scrams with Complications (USwC) indicator [8] was also developed to monitor scrams that may be potentially risk significant at the plant level using 
qualitative decision criteria and has been used since 2007. Recently, the Baseline Risk Index for Initiating Events (BRIIE) [9] was developed and has been used since 2008 in the Industry Trending Program (ITP) $)^{1}$ to monitor industry level performance in the area of initiating events using PSA results for NPPs.

The thresholds of KINS SPIs were also evaluated in the reactor safety area ${ }^{2}$ as presented in Table 1 for use in the graded inspection program. The PI thresholds must be defined considering the risk and regulatory responses to different levels of licensee performance in the graded inspection program. In this study, some modifications have been proposed for the threshold of KINS SPI. Finally, PIs and their thresholds for use in the graded regulation program are proposed in this study.

\section{FEASIBILITY STUDY OF PIS THAT USE RISK INFORMATION}

\subsection{BRIIE}

The BRIIE [9] is an industry level initiating event PI developed to monitor risk significant initiating events in the United States (US). The BRIIE consists of ten initiating events for PWR as follows ${ }^{3}$.

- General Transient (TRAN)

- Loss of Condenser Heat Sink (LOCHS)

- Loss of Main Feedwater (LOMFW)

- Loss of Offsite Power (LOOP)

- Loss of Vital AC Bus (LOAC)
- Loss of Vital DC Bus (LODC)

- Loss of Instrument Air (LOIA)

- Very Small Loss of Coolant Accident (VSLOCA)

- Stuck Open Safety Relief Valve (SORV)

- Steam Generator Tube Rupture (SGTR)

These initiating events accounted for approximately $60 \%$ of the internal event CDF risk from the 103 operating commercial nuclear power plants in the US. However, the unplanned scrams PI and loss of normal heat removal (LONHR) PI that are used to monitor initiating events in the USNRC ROP covered less than $20 \%$ of the core damage frequency (CDF), because they can only cover the general transient, loss of condenser heat sink, and loss of main feedwater PIs [9].

There is only one PI that is directly related to initiating events in the existing KINS SPI system: the unplanned reactor scrams (URS) PI. Because it considers all initiating events equally, it can be said that the SPI system only

\footnotetext{
${ }^{1}$ ITP is the program that monitors the trends in indicators of industry performance as a means to confirm that the safety of the operating power plants is being maintained

${ }^{2}$ Because PIs in the reactor safety area are regarded as the most important [1] type of PI, the threshold evaluation was limited to PIs in the reactor safety area and the evaluation of PI thresholds in the radiation safety areas remains a future study to be undertaken.

${ }^{3}$ Other remaining initiating events that contribute approximately $40 \%$ of the CDF, such as medium and large LOCAs and interfacing system LOCAs, have been excluded in the BRIIE because it was revealed that these events are rare and would not generally be expected over the lifetime of the NPPs.
}

Table 1. Safety Performance Indicators and Thresholds of KINS

\begin{tabular}{|c|c|c|c|c|c|c|}
\hline \multirow{3}{*}{ Area } & \multirow{3}{*}{ Category } & \multirow{3}{*}{$\begin{array}{l}\text { Specific Performance } \\
\text { Indicator }\end{array}$} & \multicolumn{4}{|c|}{ Grade \& Color Coding (quarterly) } \\
\hline & & & Excellent & Good & Normal & Warning \\
\hline & & & Green & Cyan & Yellow & Orange \\
\hline \multirow{9}{*}{$\begin{array}{l}\text { Reactor } \\
\text { Safety }\end{array}$} & \multirow{2}{*}{$\begin{array}{l}\text { Operational } \\
\text { Safety }\end{array}$} & Unplanned Reactor Scram & $<0.75(3 / \mathrm{yr})$ & $\geq 0.75$ (3/yr) & $\geq 1.5(6 / y r)$ & $\geq 5(20 / y r)$ \\
\hline & & Unplanned Power Reduction & $<1.5(6 / \mathrm{yr})$ & $\geq 1.5(6 / \mathrm{yr})$ & $\geq 3(12 / y r)$ & $\geq 5(20 / y r)$ \\
\hline & \multirow{4}{*}{$\begin{array}{l}\text { Multiple } \\
\text { Barrier }\end{array}$} & Fuel Reliability & $<50 \%$ TS limit & $\geq 50 \%$ TS limit & $\geq 70 \%$ TS limit & $\geq 100 \%$ TS limit \\
\hline & & Reactor Coolant Leakage & $<50 \%$ TS limit & $\geq 50 \%$ TS limit & $\geq 70 \%$ TS limit & $\geq 100 \%$ TS limit \\
\hline & & Containment Reliability & $\geq 90 \%$ & $<90 \%$ & $<80 \%$ & $<60 \%$ \\
\hline & & Emergency Preparedness & $\geq 90 \%$ & $<90 \%$ & $<80 \%$ & $<60 \%$ \\
\hline & \multirow{3}{*}{$\begin{array}{l}\text { Safety } \\
\text { System }\end{array}$} & SI System Unavailability & $<0.015$ & $\geq 0.015$ & $\geq 0.05$ & $\geq 0.1$ \\
\hline & & EDG System Unavailability & $<0.025$ & $\geq 0.025$ & $\geq 0.05$ & $\geq 0.1$ \\
\hline & & AFW System Unavailability & $<0.015$ & $\geq 0.015$ & $\geq 0.05$ & $\geq 0.1$ \\
\hline \multirow{2}{*}{$\begin{array}{l}\text { Radiation } \\
\text { Safety }\end{array}$} & On-site Rad & Radiation Collective Dose & $<1 \mathrm{manSv}$ & $\geq 1 \mathrm{manSv}$ & $\geq 3 \mathrm{manSv}$ & $\geq 5 \mathrm{manSv}$ \\
\hline & Off-site Rad & Public Dose/Environ. Rad. & $<0.0625 \mathrm{mSv}$ & $\geq 0.0625 \mathrm{mSv}$ & $\geq 0.25 \mathrm{mSv}$ & $\geq 0.6 \mathrm{mSv}$ \\
\hline
\end{tabular}


covers risks from general transient initiating events, which means that the risk coverage is very small.

Therefore, a risk coverage analysis of the BRIIE was performed as a feasibility study using the full power internal event Level 1 PSA result of Korean NPPs to examine whether the BRIIE should be adopted as an initiating event PI in Korea. Some adjustments were made in the classification of the initiating events because there were differences in the initiating events between reactor types. The results are presented in Table 2, and these demonstrate that the BRIIE can generally cover most risk significant initiating events in Korean NPPs because it covers approximately $17.5 \sim 75.6 \%$ of internal event CDF risks, whereas the general transient initiating event only covers $0.1 \sim 10.8 \%$ of internal event CDF risks. It means that the currently used URS PI cannot sufficiently cover the risks of Korean NPPs; therefore, it is necessary to adopt the BRIIE as an initiating event PI in Korea.

The BRIIE monitors the initiating events against the pre-defined industry level performance thresholds. These performance thresholds are called as 'prediction limits' that and represent the upper limits (95 percentile value) of initiating events counted in a year that, if reached or exceeded, indicate a potential degradation of industry performance. For example, given that the estimated number of general transient events in US PWRs per year is 46.6, more than 59 occurrences of general transients indicate a potential degradation of industry performance because it represents 95 percentile value, as presented in Table 3.

A preliminary estimation of the prediction limit of BRIIE was performed using the negative binomial distribution method used in the USNRC [9] and the initiating event frequency data of Korean NPPs described in Park et al.'s paper [10]. The prediction limits of the BRIIE for each initiating event can be derived using the negative binomial distribution. If an initiating event occurrence rate, $\lambda$, has a Gamma $(\alpha, \beta)$ distribution, and if $X$ given $\lambda$ has a Poisson $(\lambda t)$ distribution, for a known $t$, then the unconditional Gamma-Poisson distribution of $X$ is negative binomial:

$$
\begin{gathered}
\operatorname{Pr}(X=x)=[\Gamma(\alpha+x) / \Gamma(\alpha) x !] p^{\alpha}(1-p)^{x}, \\
x=0,1,2, \ldots,
\end{gathered}
$$

where

$p=\beta /(\beta+t), \beta=$ Baseline critical period (reactor critical years) in the past,

$t=$ Estimated reactor critical year for plant group,

$\alpha=$ Number of events in the baseline period $\beta+0.5$,

$\Gamma(x)=$ Gamma function of $x, \Gamma(x)=(x-1)$ ! if $x$ is an integer.

Then, the 95 percentile value of $\mathrm{x}$ in the probability distribution of $\mathrm{X}$ is defined as the prediction limit of BRIIE, as follows:

$$
\operatorname{Pr}(X \geq x)=1-I(p ; \alpha, x+1) \leq 0.05
$$

where

\begin{tabular}{|c|c|c|c|c|c|c|c|c|c|c|c|}
\hline \multirow{2}{*}{ Initiating Events in BRIIE } & \multicolumn{2}{|c|}{ WH900 } & \multicolumn{2}{|c|}{ WH600 } & \multicolumn{4}{|c|}{ OPR1000 } & \multirow{2}{*}{\begin{tabular}{|c|} 
Framatome \\
$\mathrm{I}$ \\
\end{tabular}} & \multicolumn{2}{|c|}{ CANDU } \\
\hline & A & B & $\mathrm{C}$ & $\mathrm{D}$ & $\mathrm{E}$ & $\mathrm{F}$ & G & $\mathrm{H}$ & & $\mathrm{J}$ & $\mathrm{K}$ \\
\hline General Transient & 9.4 & 8.7 & 10.8 & 8.1 & 4.9 & 3.6 & 5.4 & 5.4 & 1.0 & 0.9 & 0.1 \\
\hline Loss of Condenser Heat Sink & 0.0 & 0.0 & 1.3 & 1.5 & 0.3 & 0.2 & 0.3 & 0.3 & 0.4 & 0.3 & 0.4 \\
\hline Loss of Main Feedwater & 0.0 & 0.0 & 1.0 & 1.8 & 8.6 & 9.0 & 16.8 & 16.8 & 7.4 & 0.5 & 0.0 \\
\hline Loss of Offsite Power & 2.0 & 0.8 & 13.6 & 6.6 & 7.8 & 6.9 & 6.0 & 6.2 & 23.3 & 0.3 & 34.4 \\
\hline Loss of Vital AC Bus & 0.0 & 0.0 & 4.7 & 1.8 & 0.0 & 0.0 & 0.0 & 0.0 & 0.0 & 0.0 & 0.0 \\
\hline Loss of Vital DC Bus & 5.9 & 3.4 & 1.0 & 0.3 & 9.9 & 7.2 & 4.9 & 4.9 & 6.7 & 0.0 & 0.0 \\
\hline Loss of Instrument Air & 0.0 & 0.0 & 35.8 & 0.0 & 0.0 & 0.0 & 0.0 & 0.0 & 0.0 & 0.4 & 20.7 \\
\hline Very Small LOCA & \multirow{2}{*}{17.0} & \multirow{2}{*}{19.2} & \multirow{2}{*}{6.6} & \multirow{2}{*}{8.1} & \multirow{2}{*}{15.4} & \multirow{2}{*}{14.7} & \multirow{2}{*}{20.8} & \multirow{2}{*}{20.7} & \multirow{2}{*}{5.5} & \multirow{2}{*}{12.7} & \multirow{2}{*}{1.0} \\
\hline Stuck Open SRV & & & & & & & & & & & \\
\hline Steam Generator Tube Rupture & 2.6 & 2.3 & 0.9 & 7.1 & 7.8 & 9.0 & 8.5 & 8.4 & 7.3 & 2.4 & 0.3 \\
\hline Total & $36.8 \%$ & $34.4 \%$ & $75.6 \%$ & $35.6 \%$ & $54.8 \%$ & $50.5 \%$ & $62.9 \%$ & $62.6 \%$ & $51.6 \%$ & $17.5 \%$ & $57.0 \%$ \\
\hline
\end{tabular}

$I(x)=$ Negative binomial distribution of $x$

Table 2. Internal Event CDF Risk Coverage of the BRIIE in Korean NPPs (\%) 
For example, if the mean frequency of a general transient is $9.10 \mathrm{E}-01$ and its baseline critical period is 195.51, then the average number of event occurrences during the baseline critical period is $178(=9.10 \mathrm{E}-01 *$ 195.51). If it is assumed that 20 reactors are operating with $90 \%$ availability, the expected critical period per year is 18 years $(=20 * 0.9)$ and the estimated number of events per year is $16.38(=9.10 \mathrm{E}-01 * 18)$. Finally, the prediction limit of the general transient can be derived using equation (2) as follows:

$$
\begin{aligned}
& \operatorname{Pr}(X \geq 21)=1-I(0.9157 ; 178.5,22)=0.033, \\
& \operatorname{Pr}(X \geq 20)=1-I(0.9157 ; 178.5,21)=0.053,
\end{aligned}
$$

where

$$
\begin{aligned}
& \beta=195.51, \\
& t=18, \\
& p=0.9157=229.92 /(229.82+18), \\
& \alpha=178.5 .
\end{aligned}
$$

Thus, the prediction limit of the general transient is determined as 21 per year because $\operatorname{Pr}(X \geq 21) \leq 0.05$.

The derived prediction limits for Korean NPPs are presented in Table 4. These show that the value of the derived prediction limits are almost $1 / 5 \sim 1 / 2$ of the prediction limits for the US PWRs presented in Table 3.
A specific Korean prediction limit, which is different from that of the US industry, should be used if BRIIE is selected as the initiating PI for Korean NPPs.

The BRIIE cannot be directly used in graded regulations for individual NPPs because the BRIIE is an industry level PI. Therefore, it is not necessary to include the BRIIE in the KINS SPI program. However, it may be necessary to adopt the BRIIE as an industry level initiating event PI in Korea, because the risk significant initiating events can be effectively monitored using the BRIIE.

\subsection{USwC}

The USwC is used as a plant level initiating event PI in the US ROP [8]; it replaced the previous PI named LONHR, because the LONHR PI did not adequately reflect the complicated scrams that result in operator challenges. The USwC monitors unplanned automatic and manual scrams that require additional operator actions beyond that of a 'normal' scram. Such events or conditions typically present more challenges to the operators and

\begin{tabular}{|c|c|c|c|c|}
\hline Initiating Events & $\begin{array}{l}\text { Mean Frequency } \\
(1 / \text { rcry })^{9}\end{array}$ & $\begin{array}{l}\text { Estimated rcry Per } \\
\text { Year for Plant Group }\end{array}$ & $\begin{array}{c}\text { Estimated Number of } \\
\text { Events Per Year }\end{array}$ & $\begin{array}{l}95 \text { Percentile } \\
\text { Prediction Limit } \\
\text { (US PWRs) }\end{array}$ \\
\hline General Transient - PWR & $7.51 \mathrm{E}-01$ & 62.1 & 46.6 & 59 \\
\hline General Transient - BWR & 8.30E-01 & 30.6 & 25.4 & 35 \\
\hline Loss of Condenser Heat Sink - PWR & 8.11E-02 & 62.1 & 5.0 & 10 \\
\hline Loss of Condenser Heat Sink - BWR & $1.97 \mathrm{E}-01$ & 30.6 & 6.0 & 11 \\
\hline Loss of Main Feedwater & $9.59 \mathrm{E}-02$ & 92.7 & 8.9 & 15 \\
\hline Loss of Offsite Power & $3.59 \mathrm{E}-02$ & 92.7 & 3.3 & 8 \\
\hline Loss of Vital AC Bus & $8.80 \mathrm{E}-03$ & 92.7 & 0.8 & 3 \\
\hline Loss of Vital DC Bus & $1.17 \mathrm{E}-03$ & 92.7 & 0.1 & 2 \\
\hline Stuck Open SRV - PWR & $2.88 \mathrm{E}-03$ & 62.1 & 0.2 & 2 \\
\hline Stuck Open SRV - BWR & 2.23E-02 & 30.6 & 0.7 & 3 \\
\hline Loss of Instrument Air - PWR & $9.81 \mathrm{E}-03$ & 62.1 & 0.6 & 3 \\
\hline Loss of Instrument Air - BWR & $1.02 \mathrm{E}-02$ & 30.6 & 0.3 & 2 \\
\hline Very Small LOCA & $1.55 \mathrm{E}-03$ & 92.7 & 0.1 & 2 \\
\hline Steam Generator Tube Rupture - PWR & $3.54 \mathrm{E}-03$ & 62.1 & 0.2 & 2 \\
\hline
\end{tabular}
may therefore be more risk important than uncomplicated scrams. Table 5 shows the six categories that have been developed to monitor the uncomplicated scrams for

\footnotetext{
${ }^{9}$ rcry: reactor critical year
}

Table 3. Performance-Based Prediction Limits of BRIIE in US NPPS 
PWRs in the US: the six categories represent reactivity control, turbine trip, power available to emergency buses, safety injection, availability of main feedwater and utilization of scram recovery EOPs.

A threshold of greater than one complicated scram in the previous four quarters was selected as the Green/White threshold for this indicator for US NPPs. The reference document [8] states that the threshold was based on an evaluation of the US industry performance data (collected from 1995 to 2000) which results in approximately $5 \%$ of the NPPs exceeding the proposed threshold. It also states that thresholds are not provided for the Yellow or Red performance levels because the supplemental inspections in the US ROP provide an appropriate response, and the data available to establish appropriate Yellow or Red thresholds is exceedingly sparse.

As a feasibility study of the USwC PI for Korean
NPPs, a pilot evaluation of the scrams in Korean NPPs was undertaken over five years (from 2002.10.1 to 2007.9.30) to determine whether the scram is USwC or not. Of the 97 scrams during the five year study period, only seven scrams were preliminarily determined to be USwC and one out of twenty plants exceeded the Green/White threshold (more than one complicated scram in the previous four quarters). Therefore, the same threshold of the USwC in the US ROP may be used as the threshold of the USwC for Korean NPPs. Tables 6 and 7 demonstrate the USwC PI results analyzed in this study and the KINS reactor scram SPI results in the third quarter of 2007 for comparison.

${ }^{10}$ Stuck Open SRV initiating event is not considered because there were no explicit data available in the reference [10].

Table 4. Preliminary Results for Prediction Limits (95\%) of Korean NPPs ${ }^{10}$

\begin{tabular}{|c|c|c|c|c|}
\hline Initiating Events & Mean Frequency & Baseline Period (yr) & $\begin{array}{c}\text { Baseline Critical } \\
\text { Period (yr) }\end{array}$ & $\begin{array}{c}95 \text { Percentile } \\
\text { Prediction Limit } \\
\text { (Korean NPPs) }\end{array}$ \\
\hline General Transient & $9.10 \mathrm{E}-01$ & 229.82 & 195.51 & 21 \\
\hline Loss of Condenser Heat Sink & 2.04E-01 & 229.82 & 195.51 & 6 \\
\hline Loss of Main Feedwater & $5.36 \mathrm{E}-02$ & 229.82 & 195.51 & 3 \\
\hline Loss of Offsite Power & 3.93E-02 & 229.82 & 195.51 & 2 \\
\hline Loss of Vital AC Bus & $1.43 \mathrm{E}-02$ & 229.82 & 195.51 & 1 \\
\hline Loss of Vital DC Bus & $1.06 \mathrm{E}-02$ & 229.82 & 195.51 & 1 \\
\hline Loss of Instrument Air & $1.78 \mathrm{E}-02$ & 229.82 & 195.51 & 1 \\
\hline Small LOCA & $1.55 \mathrm{E}-03$ & 459.64 & 391.02 & 1 \\
\hline Steam Generator Tube Rupture & $1.06 \mathrm{E}-02$ & 229.82 & 195.51 & 1 \\
\hline
\end{tabular}

Table 5. Category and Criteria of USwC for PWR in US

\begin{tabular}{c|c}
\hline Category & USwC Criteria \\
\hline Reactivity Control & Did two or more control rods fail to fully insert? \\
\hline Turbine Trip & Did the turbine fall to trip? \\
\hline Power Available to Emergency Busses & Was power lost to any ESF bus? \\
\hline Need to actuate emergency injection sources & Was a Safety Injection signal received? \\
\hline Availability of Main Feedwater & $\begin{array}{c}\text { Was the MF unavailable or not recoverable using approved plant procedures following } \\
\text { EOP? }\end{array}$ \\
\hline Utilization of scram recovery EOPs & Was the scram response procedure unable to be completed without re-entering another \\
\hline
\end{tabular}




\subsection{MSPI}

\subsubsection{Definition and Formulation of the MSPI}

The MSPI is used as a plant level mitigating system PI in the US ROP. MSPI replaced a previous PI named safety system unavailability (SSU), because SSU had several weaknesses in application as follows: it could not consider the plant-specific risk characteristics, did not have accurate unreliability, could not directly measure the performance of the cooling water support systems, etc. [6]. These problems were resolved after implementing

Table 6. USwC Analysis Results of Korean NPPs

\begin{tabular}{|c|c|c|c|c|c|c|c|c|}
\hline NPPs & Quarter & Event description & $\begin{array}{c}\text { Reactivity } \\
\text { control }\end{array}$ & $\begin{array}{c}\text { Turbine } \\
\text { trip }\end{array}$ & $\begin{array}{c}\text { Power } \\
\text { available }\end{array}$ & SI signal & Main feed & $\begin{array}{c}\text { Another } \\
\text { EOP }\end{array}$ \\
\hline NPP6 & 3Q2007 & $\begin{array}{l}\text { Reactor scram by trip of main } \\
\text { feedwater pumps }\end{array}$ & $\mathrm{N}$ & $\mathrm{N}$ & $\mathrm{N}$ & $\mathrm{N}$ & $\mathrm{Y}$ & $\mathrm{N}$ \\
\hline NPP6 & 4Q2006 & $\begin{array}{l}\text { Reactor subcriticality entrance due } \\
\text { to opened pressurizer spray valve }\end{array}$ & $\mathrm{Y}$ & $\mathrm{N}$ & $\mathrm{N}$ & $\mathrm{Y}$ & $\mathrm{N}$ & $\mathrm{N}$ \\
\hline NPP17 & 3Q2006 & $\begin{array}{c}\text { Reactor scram by loss of } \\
\text { feedwater due to deaerator water } \\
\text { level controller failure }\end{array}$ & $\mathrm{N}$ & $\mathrm{N}$ & $\mathrm{N}$ & $\mathrm{N}$ & Y & $\mathrm{N}$ \\
\hline NPP1 & 2Q2005 & $\begin{array}{l}\text { Safety injection and reactor scram } \\
\text { during test at zero reactor power }\end{array}$ & $\mathrm{N}$ & $\mathrm{N}$ & $\mathrm{N}$ & $\mathrm{Y}$ & $\mathrm{N}$ & $\mathrm{N}$ \\
\hline NPP9 & 1Q2005 & $\begin{array}{l}\text { Turbine/generator and reactor trip } \\
\text { by loss of condenser vacuum }\end{array}$ & $\mathrm{N}$ & $\mathrm{N}$ & $\mathrm{N}$ & $\mathrm{N}$ & $\mathrm{Y}$ & $\mathrm{N}$ \\
\hline NPP8 & 4Q2003 & $\begin{array}{c}\text { Reactor scream and safety } \\
\text { injection by inadequate feedwater } \\
\text { flow control }\end{array}$ & $\mathrm{N}$ & $\mathrm{N}$ & $\mathrm{N}$ & $\mathrm{Y}$ & $\mathrm{N}$ & $\mathrm{N}$ \\
\hline NPP15 & 1Q2003 & $\begin{array}{c}\text { Safety injection and reactor scram } \\
\text { by rapid pressure decrease of main } \\
\text { steam line }\end{array}$ & $\mathrm{N}$ & $\mathrm{N}$ & $\mathrm{N}$ & $\mathrm{Y}$ & $\mathrm{N}$ & $\mathrm{N}$ \\
\hline
\end{tabular}

Table 7. Result of USwC and Reactor Scram PI in the Third Quarter 2007

\begin{tabular}{|c|c|c|c|c|c|}
\hline Unit & USwC & $\begin{array}{l}\text { Reactor Scram } \\
\quad(\text { KINS) }\end{array}$ & Unit & USwC & $\begin{array}{c}\text { Reactor Scram } \\
\text { (KINS) }\end{array}$ \\
\hline NPP1 & $\mathrm{N}$ & $\mathrm{N}$ & NPP11 & Green & Green \\
\hline NPP2 & Green & Green & NPP12 & Green & Green \\
\hline NPP3 & Green & Green & NPP13 & Green & Green \\
\hline NPP4 & Green & Green & NPP14 & Green & Green \\
\hline NPP5 & Green & Green & NPP15 & Green & Green \\
\hline NPP6 & White & Yellow & NPP16 & Green & Green \\
\hline NPP7 & Green & Green & NPP17 & Green & Green \\
\hline NPP8 & Green & Green & NPP18 & Green & Green \\
\hline NPP9 & Green & Green & NPP19 & Green & Green \\
\hline NPP10 & Green & Cyan & NPP20 & Green & Green \\
\hline
\end{tabular}


the MSPI, because the MSPI can consider the dissimilarities in design and operation of NPPs using the plant-specific PSA results. The existing KINS SPI system uses an SSU similar to that was used in the USNRC; therefore, the KINS SPI system has the same weaknesses as the SSU used in the USNRC. Thus, the MSPI implementation will also be beneficial for the graded inspection program in Korea because the plant-specific risk characteristics of NPPs can be incorporated by using the MSPI.

Five systems are monitored in MSPI: emergency AC power system (EAC), high pressure injection system (HPSI), auxiliary feedwater system (AFW), residual heat removal system (RHR), and cooling water support system. The MSPI of a given system is a simplified linear approximation of the change in the core damage frequency (CDF) attributable to changes in the reliability and availability of risk significant elements of the system. Thus, the calculation focuses on key components and quantifies the change in CDF using a simple formula based on the sum of the changes in the unreliability index (URI) and the unavailability index (UAI), as follows:

$$
M S P I=U A I+U R I,
$$

$$
\begin{aligned}
& U R I=C D F_{b} * \sum_{i} A_{i}^{*}\left[F V\left(U R_{i}\right) / U R_{i}\right] *\left(U R_{c i}-U R_{b j}\right) \\
& =\Sigma_{i} A_{i}{ }^{*} B\left(U R_{i}\right) *\left(U R_{c i}-U R_{b i}\right) \\
& =\Sigma_{i} A_{i} * B\left(U R_{i}\right) * \Delta U R_{i}, \\
& \left.U A I=C D F_{b} * \Sigma_{j}\left[F V\left(U A_{j}\right) / U A_{j}\right)\right] *\left(U A_{c j}-U A_{b j}\right) \\
& =\Sigma_{j} B\left(U A_{j}\right) *\left(U A_{c j}-U A_{b j}\right) \\
& =\Sigma_{j} B\left(U A_{j}\right) * \Delta U A_{j},
\end{aligned}
$$

where

$C D F_{b} \quad=$ Baseline Core damage frequency (from plant PSA),

$U R_{i} \quad=$ Component $i$ unreliability,

$\mathrm{FV}\left(\mathrm{UR}_{i}\right)^{4}=$ Fussell-Vesely importance of component

\begin{tabular}{|c|c|c|}
\hline Component & Failure Mode & Baseline Unreliability \\
\hline Circuit breaker & Fail to open (or close) & $8.00 \mathrm{E}-04$ \\
\hline Hydraulic-operated valve & Fail to open (or close) & $1.00 \mathrm{E}-03$ \\
\hline Motor-operated valve & Fail to open (or close) & $7.00 \mathrm{E}-04$ \\
\hline Solenoid-operated valve & Fail to open (or close) & $1.00 \mathrm{E}-03$ \\
\hline Air-operated valve & Fail to open (or close) & $1.00 \mathrm{E}-03$ \\
\hline \multirow{2}{*}{ Motor-driven pump, standby } & Fail to start & $1.90 \mathrm{E}-03$ \\
\hline & Fail to run & $5.00 \mathrm{E}-05$ \\
\hline \multirow{2}{*}{ Motor-driven pump, running/alternating } & Fail to start & $1.00 \mathrm{E}-03$ \\
\hline & Fail to run & $5.00 \mathrm{E}-06$ \\
\hline \multirow{2}{*}{ Turbine-driven pump, AFWS } & Fail to start & $9.00 \mathrm{E}-03$ \\
\hline & Fail to run & $2.00 \mathrm{E}-04$ \\
\hline \multirow{2}{*}{ Turbine-driven pump, HPCI or RCIC } & Fail to start & $1.30 \mathrm{E}-02$ \\
\hline & Fail to run & $2.00 \mathrm{E}-04$ \\
\hline \multirow{2}{*}{ Diesel-driven pump, AFWS } & Fail to start & $1.20 \mathrm{E}-02$ \\
\hline & Fail to run & $2.00 \mathrm{E}-04$ \\
\hline \multirow{3}{*}{ Emergency diesel generator } & Fail to start & $5.00 \mathrm{E}-03$ \\
\hline & Fail to load/run & $3.00 \mathrm{E}-03$ \\
\hline & Fail to run & $8.00 \mathrm{E}-04$ \\
\hline
\end{tabular}
$i$ unreliability (from plant PSA),

$A_{i} \quad=$ CCF multiplier of component $i$ (from plant PSA),

$U R_{c i} \quad=$ Current component $i$ unreliability (Bayesian update using data from most recent 3 years),

Table 8. Baseline Unreliability Used for MSPI in US Industry [2] 

$U R_{b i} \quad=$ Baseline component $i$ unreliability (from NEI data as presented in Table 8),
$B\left(U R_{i}\right)=$ Birnbaum importance of component $i$ unreliability (from plant PSA),
$F V\left(U A_{j}\right)=$ Fussell-Vesely importance of train $j$ unavailability (from plant PSA),
$U A_{c j} \quad=$ Current train $j$ unavailability (data from most recent 3 years),
$U A_{b j} \quad=$ Baseline train $j$ unavailability (from NEI data as presented in Table 9),
$B\left(U A_{j}\right) \quad=$ Birnbaum importance of train $j$ unavailability (from plant PSA).

In practice, the number of component failure $s$ is generally the most dominant contributor in the MSPI, which means the URI is a more dominant contributor than the UAI [11]. The CCF multiplier (Aj) in equation (3) is used in the URI calculation to include the CCF contribution. The licensee can use both the generic and the plant-specific CCF multiplier. In the US, most licensees used the generic CCF multiplier [2, 12]. The plant-specific CCF multiplier can generally be derived as follows:

$$
A_{i}=\left(\sum_{i} F V_{\text {independent }, i}+F V_{C C F}\right) / F V_{\text {independent }, i} \text {, }
$$

where

$$
\begin{aligned}
F V_{\text {independen }, i}= & \text { Fussell-Vesely importance of independent } \\
& \text { basic event i in CCF group, } \\
F V_{C C F}= & \text { Fussell-Vesely importance of CCF basic } \\
& \text { events. }
\end{aligned}
$$

The Birnbaum importance is the partial derivative of the CDF with respect to the basic event probability in a
PSA model that provides a measure of the risk sensitivity of a plant component to the CDF. The Birnbaum importance value is a critical input to the MSPI calculation and is determined by the plant-specific PSA model. Extensive cross comparison studies of the Birnbaum importance value including the CCF multiplier have been performed in the USNRC and within the industry [12] before the MSPI implementation because an important aspect of the PSA quality for the MSPI implementation is comparing the Birnbaum values within different classes of plant design.

The performance thresholds of the MSPI are based on the CDF thresholds because the MSPI of a given system is a linear approximation of the CDF. However, an unexpectedly large number of failures would be required for entry into the 'White' threshold if only CDF thresholds are used, when the Birnbaum importance values for a given system are relatively small. Therefore, the additional performance thresholds called 'backstops' are used to preclude a situation where an unexpectedly large number of failures occur before reaching the 'White' threshold. The backstop value is based on the statistical significance of the observed number of failures relative to prior expectations. The performance thresholds of the MSPI are defined as follows:

$$
\begin{aligned}
& \text { Green }=\text { if } M S P I \leq 1.0 E-06 \text { and } F_{a} \leq F_{m} \\
& \text { White }=\text { if } 1.0 E-06<M S P I \leq 1.0 E-05 \text { or } F_{a}>F_{m}
\end{aligned}
$$

${ }^{4} F V$ (Fussell-Vesely) importance can be derived as follows: $F V(U R i)=\left(C D F_{b}-C D F(i=0)\right) / C D F_{b}$ where $C D F_{b}=$ Baseline $C D F$

$C D F(i=0)=C D F$ with component unreliability is zero.

Table 9. Baseline Unavailability Used for MSPI in US Industry [2]

\begin{tabular}{c|c|c}
\hline System & Train Type & Baseline Unavailability \\
\hline Emergency AC power system & Emergency diesel generator & $1.30 \mathrm{E}-02$ \\
\hline High pressure injection system & Motor-operated valve & $5.80 \mathrm{E}-03$ \\
\hline High pressure coolant injection & Turbine-driven pump & $4.00 \mathrm{E}-02$ \\
\hline \multirow{2}{*}{ Auxiliary feedwater system } & Motor-driven pump & $4.80 \mathrm{E}-03$ \\
\cline { 2 - 3 } & Turbine-driven pump & $4.90 \mathrm{E}-03$ \\
\cline { 2 - 3 } & Diesel-driven pump & $1.20 \mathrm{E}-02$ \\
\hline Reactor core isolation cooling & Turbine-driven pump & $6.20 \mathrm{E}-03$ \\
\hline Residual heat removal system (BWR) & Motor-driven pump & $6.00 \mathrm{E}-03$ \\
\hline Service water system & Motor-driven pump & $2.00 \mathrm{E}-02$
\end{tabular}


Yellow $=$ if $1.0 E-05<M S P I \leq 1.0 E-04$

Red $=$ if $M S P I>1.0 E-04$

where

$F_{a} \quad=$ Actual numbers of equipment failures,

$F_{m} \quad=$ Backstop value of equipment .

The backstop values are determined as follows:

$$
\begin{gathered}
F_{m}=4.65^{*} F_{e}+4.2, \\
F_{e}=N_{d}^{*} p+\lambda^{*} T_{r},
\end{gathered}
$$

where

$$
\begin{aligned}
F_{e} & =\text { Expected number of failures, } \\
N_{d} & =\text { Number of demands, } \\
p & = \\
& \text { Probability of failure on demand presented } \\
\lambda \quad= & \text { Running failure rate presented in Table } 9 \\
& \text { (industry average value; NEI) } \\
T_{r} \quad= & \text { Runtime of the component. }
\end{aligned}
$$

\subsubsection{Application Study}

In this study, a pilot study for the implementation of the MSPI in Korea was undertaken. Previously, Kang et al. [13] undertook an application study of the MSPI and derived several insightful results and recommendations; however, they only used an OPR1000 Level 1 PSA result. Because the MSPI must be used for all NPPs, a feasibility study of the MSPI implementation using the PSA results of different reactor types is needed. The Birnbaum values that are critical inputs into the MSPI calculation are different between the PSA result of each reactor type due to the differences in plant design, operation, PSA modeling assumptions, etc. These differences in the Birnbaum values will cause different results in the MSPI and safety grade (Green, White, Yellow, Red) of each reactor type despite having the same number of failures occur.

In these circumstances, a sensitivity analysis of the MSPI was performed for the five representative types of Korean NPPs (WH900, WH600, OPR1000, Framatome, and CANDU). The purpose of the sensitivity analyses was to verify the expected differences in the $\mathrm{MSPI}^{5}$ results for each reactor type as a function of the demand failure numbers. These analyses are similar to the 'MSPI margin analyses' conducted in the US [11]. The sensitivity analyses were performed by changing the demand failure numbers of one typical component at a time for the frontline safety systems of MSPI . Motordriven pumps (MDP) and emergency diesel generators (EDG) were selected as typical components for the MSPI sensitivity analyses of each system. The unreliability and unavailability by other components (e.g. motor-operated valves) were assumed to be the same as the industry baseline values.

Three types of MSPI sensitivity analyses were performed in this study. The values of the MSPI as a function of the demand failure numbers were derived: a) using the generic CCF multipliers, b) using the plantspecific CCF multipliers, and c) using the backstops and plant-specific CCF multipliers.

a) MSPI sensitivity analysis using generic CCF multipliers

The generic CCF multipliers applied in the demand failure of pumps and diesel generators for the five types of Korean NPPs are presented in Table 10. These were derived from the values used in the independent MPSI verification studies undertaken by the USNRC [6] as presented in Table 11. As stated previously, a licensee in the US industry can use both the generic or plant-specific CCF multiplier, but most licensees use the generic CCF multiplier.

The highest CCF adjusted Birnbaums for each component using the generic CCF multipliers are presented in Table 12. These were derived by multiplying the generic CCF multipliers in Table 10 to the independent demand failure Birnbaums of the individual components.

\begin{tabular}{|c|c|c|c|c|c|}
\hline System-Component & WH900 & WH600 & OPR1000 & Framatome & CANDU \\
\hline EAC-EDG & & & 1.25 & 1.50 & \\
\hline HPSI-MDP & 1.50 & 3.00 & 3.00 & & 3.00 \\
\hline RHR-MDP & & & 1.50 & & \\
\hline AF-MDP & & & 1.25 & & 1.00 \\
\hline
\end{tabular}

In Tables 13 to 16 , the MPSI sensitivity results are

\footnotetext{
${ }^{5}$ Sensitivity analyses for the cooling water support system have not yet been performed and remain for future study. There are various methods for deriving the importance of the cooling water support system components, because the cooling water support system not only has a mitigation function but also results in an event initiation.
}

Table 10. Generic CCF Multipliers Applied for Demand Failure of Pumps and Diesel Generators in the Five Types of Korean NPPs 
Table 11. Generic CCF Multipliers Presented in NUREG-1816

\begin{tabular}{|c|c|c|c|c|c|c|}
\hline & & \multicolumn{5}{|c|}{ Generic CCF Multipliers } \\
\hline System & Component & 1.25 & 1.50 & 2.00 & 3.00 & 5.00 \\
\hline EAC & EDG & $\begin{array}{c}2 \operatorname{EDGS}(1 / 2) \text { or } \\
3 \operatorname{EDGS}(2 / 3)\end{array}$ & $\begin{array}{c}4 \text { EDGS }(1 / 4) \\
\text { with other diverse } \\
\text { sources of power }\end{array}$ & 3 EDGS $(1 / 3)$ & & $\begin{array}{c}4 \text { EDGS }(1 / 4) \text { and } \\
\text { no diverse } \\
\text { sources of power }\end{array}$ \\
\hline \multirow[t]{2}{*}{ HPSI } & MDP Running & & $\begin{array}{c}\text { With SI and } \\
\text { CVC }^{11}\end{array}$ & & With only CVC & \\
\hline & MDP Standby & & With SI and CVC & & With only SI & \\
\hline \multirow[t]{2}{*}{$\mathrm{HRS}^{12}$} & MDP Standby & $2 \operatorname{MDPS}(1 / 2)$ & & & 3 MDPS (1/3) & \\
\hline & $\mathrm{TDP}^{13}$ & $\begin{array}{c}2 \text { TDPS and } 1 \\
\text { MDP }\end{array}$ & & & $\begin{array}{c}3 \text { TDPS and no } \\
\text { MDPS }\end{array}$ & \\
\hline RHR & MDP Standby & & All & & & \\
\hline \multirow[t]{3}{*}{$\mathrm{SWS}^{14}$} & MDP Running & & & & All & \\
\hline & MDP Standby & & All & & & \\
\hline & DDP & All & & & & \\
\hline \multirow[t]{2}{*}{ CCW } & MDP Running & & All & & & \\
\hline & MDP Standby & & & All & & \\
\hline All & MOV & & & All & & \\
\hline All & $\mathrm{AOV}^{15}$ & & All & & & \\
\hline
\end{tabular}

Table 12. Highest CCF Adjusted Birnbaums for Demand Failure of Pumps and Diesel Generators Using the Generic CCF Multipliers

\begin{tabular}{c|c|c|c|c|c}
\hline System-Component & WH900 & WH600 & OPR1000 & Framatome & CANDU \\
\hline EAC-EDG & $7.80 \mathrm{E}-05$ & $3.53 \mathrm{E}-05$ & $4.91 \mathrm{E}-06$ & $1.62 \mathrm{E}-04$ & $9.76 \mathrm{E}-06$ \\
\hline HPSI-MDP & $6.61 \mathrm{E}-07$ & $6.58 \mathrm{E}-06$ & $4.14 \mathrm{E}-05$ & $2.57 \mathrm{E}-07$ & $7.76 \mathrm{E}-07$ \\
\hline RHR-MDP & $9.32 \mathrm{E}-06$ & $1.07 \mathrm{E}-05$ & $6.68 \mathrm{E}-06$ & $2.62 \mathrm{E}-07$ & $7.28 \mathrm{E}-06$ \\
\hline AF-MDP & $5.83 \mathrm{E}-05$ & $4.40 \mathrm{E}-06$ & $5.19 \mathrm{E}-05$ & $1.51 \mathrm{E}-06$ & $5.19 \mathrm{E}-06$ \\
\hline
\end{tabular}

presented as a function of the component demand failure numbers during three years of operation while the Birnbaums with the generic CCF multipliers are applied. The MSPI results including color coding (Green, White, Yellow, Red) for the five types of NPPs differ significantly from each other for the same number of demand failures. Generally, the MSPI results of the EAC were the most sensitive to the number of failures due to the high Birnbaum and high failure rate of EDGs, which is the same as the US industry MSPI implementation experiences
[11]. The MSPI results of some systems remained 'Green' even if a large number of failures occurred as a result of relatively small Birnbaums. This type of indicator is

\footnotetext{
${ }^{11}$ CVC: Chemical and Volume Control System

${ }^{12}$ HRS: Heat Removal System

${ }^{13}$ CVC: Chemical and Volume Control System

${ }^{14}$ TDP: Turbine-driven pump

${ }^{15}$ AOV: Air-operated valve
} 
Table 13. MSPI Sensitivity Results Using the Generic CCF Multiplier (EAC-EDG)

\begin{tabular}{|c|c|c|c|c|c|}
\hline $\begin{array}{l}\text { Demand Failures in } \\
\text { Three Years }\end{array}$ & WH900 & WH600 & OPR1000 & Framatome & CANDU \\
\hline 0 & $-2.23 \mathrm{E}-08(\mathrm{G})$ & $-8.57 \mathrm{E}-08(\mathrm{G})$ & $-2.07 \mathrm{E}-08(\mathrm{G})$ & $-6.41 \mathrm{E}-07(\mathrm{G})$ & $-3.82 \mathrm{E}-08(\mathrm{G})$ \\
\hline 1 & $3.96 \mathrm{E}-08(\mathrm{G})$ & $1.52 \mathrm{E}-07(\mathrm{G})$ & $3.67 \mathrm{E}-08(\mathrm{G})$ & $1.14 \mathrm{E}-06(\mathrm{~W})$ & $6.80 \mathrm{E}-08(\mathrm{G})$ \\
\hline 2 & $1.02 \mathrm{E}-07(\mathrm{G})$ & $3.91 \mathrm{E}-07(\mathrm{G})$ & $9.41 \mathrm{E}-08(\mathrm{G})$ & $2.92 \mathrm{E}-06(\mathrm{~W})$ & $1.74 \mathrm{E}-07(\mathrm{G})$ \\
\hline 3 & $1.63 \mathrm{E}-07(\mathrm{G})$ & $6.29 \mathrm{E}-07(\mathrm{G})$ & $1.52 \mathrm{E}-07(\mathrm{G})$ & $4.70 \mathrm{E}-06(\mathrm{~W})$ & $2.80 \mathrm{E}-07(\mathrm{G})$ \\
\hline 4 & $2.25 \mathrm{E}-07(\mathrm{G})$ & 8.67E-07 (G) & $2.09 \mathrm{E}-07(\mathrm{G})$ & $6.48 \mathrm{E}-06(\mathrm{~W})$ & $3.86 \mathrm{E}-07(\mathrm{G})$ \\
\hline 5 & $2.87 \mathrm{E}-07(\mathrm{G})$ & $1.11 \mathrm{E}-06(\mathrm{~W})$ & $2.66 \mathrm{E}-07(\mathrm{G})$ & $8.27 \mathrm{E}-06(\mathrm{~W})$ & $4.93 \mathrm{E}-07(\mathrm{G})$ \\
\hline 6 & $3.49 \mathrm{E}-07(\mathrm{G})$ & $1.34 \mathrm{E}-06(\mathrm{~W})$ & $3.24 \mathrm{E}-07(\mathrm{G})$ & $1.00 \mathrm{E}-05(\mathrm{Y})$ & 5.99E-07 (G) \\
\hline 7 & 4.11E-07 (G) & $1.58 \mathrm{E}-06(\mathrm{~W})$ & 3.81E-07 (G) & $1.18 \mathrm{E}-05(\mathrm{Y})$ & $7.05 \mathrm{E}-07(\mathrm{G})$ \\
\hline 8 & 4.73E-07 (G) & $1.82 \mathrm{E}-06(\mathrm{~W})$ & 4.39E-07 (G) & $1.36 \mathrm{E}-05(\mathrm{Y})$ & $8.11 \mathrm{E}-07(\mathrm{G})$ \\
\hline 9 & $5.35 \mathrm{E}-07(\mathrm{G})$ & $2.06 \mathrm{E}-06(\mathrm{~W})$ & $4.96 \mathrm{E}-07(\mathrm{G})$ & $1.54 \mathrm{E}-05(\mathrm{Y})$ & $9.17 \mathrm{E}-07(\mathrm{G})$ \\
\hline 10 & $5.97 \mathrm{E}-07(\mathrm{G})$ & $2.30 \mathrm{E}-06(\mathrm{~W})$ & $5.53 \mathrm{E}-07(\mathrm{G})$ & $1.72 \mathrm{E}-05(\mathrm{Y})$ & $1.02 \mathrm{E}-06(\mathrm{~W})$ \\
\hline 11 & $6.59 \mathrm{E}-07(\mathrm{G})$ & $2.53 \mathrm{E}-06(\mathrm{~W})$ & $6.11 \mathrm{E}-07(\mathrm{G})$ & $1.90 \mathrm{E}-05(\mathrm{Y})$ & $1.13 \mathrm{E}-06(\mathrm{~W})$ \\
\hline 12 & $7.21 \mathrm{E}-07(\mathrm{G})$ & $2.77 \mathrm{E}-06(\mathrm{~W})$ & $6.68 \mathrm{E}-07(\mathrm{G})$ & $2.07 \mathrm{E}-05(\mathrm{Y})$ & $1.24 \mathrm{E}-06(\mathrm{~W})$ \\
\hline 13 & $7.83 \mathrm{E}-07(\mathrm{G})$ & $3.01 \mathrm{E}-06(\mathrm{~W})$ & $7.25 \mathrm{E}-07(\mathrm{G})$ & $2.25 \mathrm{E}-05(\mathrm{Y})$ & $1.34 \mathrm{E}-06(\mathrm{~W})$ \\
\hline 14 & $8.45 \mathrm{E}-07(\mathrm{G})$ & $3.25 \mathrm{E}-06(\mathrm{~W})$ & 7.83E-07 (G) & $2.43 \mathrm{E}-05(\mathrm{Y})$ & $1.45 \mathrm{E}-06(\mathrm{~W})$ \\
\hline 15 & $9.07 \mathrm{E}-07(\mathrm{G})$ & $3.49 \mathrm{E}-06(\mathrm{~W})$ & $8.40 \mathrm{E}-07(\mathrm{G})$ & $2.61 \mathrm{E}-05(\mathrm{Y})$ & $1.55 \mathrm{E}-06(\mathrm{~W})$ \\
\hline 16 & 9.69E-07 (G) & $3.73 \mathrm{E}-06(\mathrm{~W})$ & 8.98E-07 (G) & $2.79 \mathrm{E}-05(\mathrm{Y})$ & $1.66 \mathrm{E}-06(\mathrm{~W})$ \\
\hline 17 & $1.03 \mathrm{E}-06(\mathrm{~W})$ & $3.96 \mathrm{E}-06(\mathrm{~W})$ & $9.55 \mathrm{E}-07(\mathrm{G})$ & $2.96 \mathrm{E}-05(\mathrm{Y})$ & $1.77 \mathrm{E}-06(\mathrm{~W})$ \\
\hline 18 & $1.09 \mathrm{E}-06(\mathrm{~W})$ & $4.20 \mathrm{E}-06(\mathrm{~W})$ & $1.01 \mathrm{E}-06(\mathrm{~W})$ & $3.14 \mathrm{E}-05(\mathrm{Y})$ & $1.87 \mathrm{E}-06(\mathrm{~W})$ \\
\hline 19 & $1.15 \mathrm{E}-06(\mathrm{~W})$ & $4.44 \mathrm{E}-06(\mathrm{~W})$ & $1.07 \mathrm{E}-06(\mathrm{~W})$ & $3.32 \mathrm{E}-05(\mathrm{Y})$ & $1.98 \mathrm{E}-06(\mathrm{~W})$ \\
\hline 20 & $1.22 \mathrm{E}-06(\mathrm{~W})$ & $4.68 \mathrm{E}-06(\mathrm{~W})$ & $1.13 \mathrm{E}-06(\mathrm{~W})$ & $3.50 \mathrm{E}-05(\mathrm{Y})$ & $2.09 \mathrm{E}-06(\mathrm{~W})$ \\
\hline
\end{tabular}

generally defined as an 'insensitive indicator', which allows an unexpectedly large number of failures to occur in a system without appropriate regulatory enforcement.

These significant differences in the MSPI results between NPPs can result from the different design and operating features of each NPP, which is reasonable because a primary purpose of MSPI usage is to consider plant-specific risk characteristics. However, these significant differences in the MSPI results can also result from different data collection periods, which results in initiating event frequency difference, different common cause factor modeling assumptions, different human reliability analysis models, and so on.

For example, the MSPI results of EDGs in the OPR1000 remained 'Green' for a large number of demand failures over three years due to its lower Birnbaum compared with those of other NPPs. There are a number of reasons for the EDGs in the OPR1000 to have a relatively lower Birnbaum; for example, the AAC is modeled as a backup of the EDGs in the OPR1000 PSA model. Lowering of the Birnbaum of EDGs by modeling an installed AAC in the PSA model can be an appropriate approach because it reflects the plant-specific risk characteristics.

However, the different value of the LOOP frequency in the OPR1000 PSA compared with those of other plant types also contributed to the lower Birnbaums of the EDGs. The LOOP frequency used in the OPR1000 PSA was 2.20E-02/yr; however, increased frequencies that are almost twice that of $2.20 \mathrm{E}-02 / \mathrm{yr}$ were used in the PSA of other plant types as presented in Table 17. Because most LOOP events were weather-related events in Korea [14], the difference of the LOOP frequency is generally not related 
to NPP design differences or the results from the different initiating event data collection periods due to different revision dates of each PSA model ${ }^{6}$. In this example, the difference in the LOOP frequency can lead to different EDG MSPI results of the OPR1000 compared with other NPPs.

It will be necessary to use up-to-date initiating event data for MSPI implementation rather than using the initiating event data in the licensee PSA model. The basis of small Birnbaums for some components must be verified carefully prior to implementation of the MSPI, because some instances of small Birnbaums may not result from design differences but rather from initiating event data, PSA modeling assumptions, etc.

\section{b) MSPI sensitivity analysis using plant-specific CCF multipliers}

The plant-specific CCF multipliers were derived from equation (6) and applied in the MSPI calculation. The plant-specific CCF multipliers that were applied in the five types of Korean NPPs are presented in Table 18. The results show that most plant-specific CCF multipliers derived from the Korean PSA results are higher than the generic CCF multipliers.

The highest CCF adjusted Birnbaums for each component using the plant-specific PSA results are presented in Table 19. These were derived by multiplying the plant-specific CCF multipliers in Table 18 with the independent demand failure Birnbaums.

The MPSI sensitivity results using the plant-specific CCF multipliers are presented in Table 20 to Table 23.

\footnotetext{
${ }^{6}$ Revision year of PSA model used in this paper:WH900 (2003), WH600 (2007), OPR1000 (2004), Framatome (2005), and CANDU (2007).
}

Table 14. MSPI Sensitivity Results Using the Generic CCF Multiplier (HPSI-MDP)

\begin{tabular}{|c|c|c|c|c|c|}
\hline $\begin{array}{l}\text { Demand Failures in } \\
\text { Three Years }\end{array}$ & WH900 & WH600 & OPR1000 & Framatome & CANDU \\
\hline 0 & $-3.33 \mathrm{E}-09(\mathrm{G})$ & $-1.90 \mathrm{E}-09(\mathrm{G})$ & $-1.23 \mathrm{E}-08(\mathrm{G})$ & $-1.26 \mathrm{E}-11(\mathrm{G})$ & $-1.45 \mathrm{E}-10(\mathrm{G})$ \\
\hline 1 & 8.80E-08 (G) & $4.00 \mathrm{E}-08(\mathrm{G})$ & $2.57 \mathrm{E}-07(\mathrm{G})$ & $5.03 \mathrm{E}-10(\mathrm{G})$ & $3.05 \mathrm{E}-09(\mathrm{G})$ \\
\hline 2 & 1.79E-07 (G) & 8.19E-08 (G) & 5.27E-07 (G) & $1.02 \mathrm{E}-09(\mathrm{G})$ & $6.25 \mathrm{E}-09(\mathrm{G})$ \\
\hline 3 & $2.71 \mathrm{E}-07(\mathrm{G})$ & $1.24 \mathrm{E}-07(\mathrm{G})$ & $7.96 \mathrm{E}-07(\mathrm{G})$ & $1.53 \mathrm{E}-09(\mathrm{G})$ & $9.45 \mathrm{E}-09(\mathrm{G})$ \\
\hline 4 & $3.62 \mathrm{E}-07(\mathrm{G})$ & $1.66 \mathrm{E}-07(\mathrm{G})$ & $1.07 \mathrm{E}-06(\mathrm{~W})$ & $2.05 \mathrm{E}-09(\mathrm{G})$ & $1.26 \mathrm{E}-08(\mathrm{G})$ \\
\hline 5 & 4.53E-07 (G) & $2.08 \mathrm{E}-07(\mathrm{G})$ & $1.34 \mathrm{E}-06(\mathrm{~W})$ & $2.56 \mathrm{E}-09(\mathrm{G})$ & $1.58 \mathrm{E}-08(\mathrm{G})$ \\
\hline 6 & $5.45 \mathrm{E}-07(\mathrm{G})$ & 2.49E-07 (G) & $1.61 \mathrm{E}-06(\mathrm{~W})$ & $3.08 \mathrm{E}-09(\mathrm{G})$ & $1.90 \mathrm{E}-08(\mathrm{G})$ \\
\hline 7 & $6.36 \mathrm{E}-07(\mathrm{G})$ & $2.91 \mathrm{E}-07(\mathrm{G})$ & $1.87 \mathrm{E}-06(\mathrm{~W})$ & $3.60 \mathrm{E}-09(\mathrm{G})$ & $2.22 \mathrm{E}-08(\mathrm{G})$ \\
\hline 8 & 7.27E-07 (G) & 3.33E-07 (G) & $2.14 \mathrm{E}-06(\mathrm{~W})$ & 4.11E-09 (G) & $2.54 \mathrm{E}-08(\mathrm{G})$ \\
\hline 9 & 8.19E-07 (G) & $3.75 \mathrm{E}-07(\mathrm{G})$ & $2.41 \mathrm{E}-06(\mathrm{~W})$ & 4.63E-09 (G) & $2.86 \mathrm{E}-08(\mathrm{G})$ \\
\hline 10 & $9.10 \mathrm{E}-07$ (G) & 4.17E-07 (G) & $2.68 \mathrm{E}-06(\mathrm{~W})$ & $5.14 \mathrm{E}-09(\mathrm{G})$ & $3.18 \mathrm{E}-08(\mathrm{G})$ \\
\hline 11 & $1.00 \mathrm{E}-06(\mathrm{~W})$ & 4.59E-07 (G) & $2.95 \mathrm{E}-06(\mathrm{~W})$ & $5.66 \mathrm{E}-09(\mathrm{G})$ & $3.50 \mathrm{E}-08(\mathrm{G})$ \\
\hline 12 & 1.09E-06 (W) & 5.01E-07 (G) & $3.22 \mathrm{E}-06(\mathrm{~W})$ & 6.17E-09 (G) & $3.82 \mathrm{E}-08(\mathrm{G})$ \\
\hline 13 & $1.18 \mathrm{E}-06(\mathrm{~W})$ & $5.43 \mathrm{E}-07(\mathrm{G})$ & 3.49E-06 (W) & $6.69 \mathrm{E}-09(\mathrm{G})$ & 4.14E-08 (G) \\
\hline 14 & $1.28 \mathrm{E}-06(\mathrm{~W})$ & $5.85 \mathrm{E}-07(\mathrm{G})$ & $3.76 \mathrm{E}-06(\mathrm{~W})$ & $7.20 \mathrm{E}-09(\mathrm{G})$ & $4.46 \mathrm{E}-08(\mathrm{G})$ \\
\hline 15 & $1.37 \mathrm{E}-06(\mathrm{~W})$ & $6.27 \mathrm{E}-07(\mathrm{G})$ & 4.03E-06 (W) & 7.72E-09 (G) & $4.78 \mathrm{E}-08(\mathrm{G})$ \\
\hline 16 & $1.46 \mathrm{E}-06(\mathrm{~W})$ & $6.68 \mathrm{E}-07(\mathrm{G})$ & $4.30 \mathrm{E}-06(\mathrm{~W})$ & $8.24 \mathrm{E}-09(\mathrm{G})$ & $5.10 \mathrm{E}-08(\mathrm{G})$ \\
\hline 17 & $1.55 \mathrm{E}-06(\mathrm{~W})$ & 7.10E-07 (G) & 4.57E-06 (W) & $8.75 \mathrm{E}-09(\mathrm{G})$ & $5.42 \mathrm{E}-08(\mathrm{G})$ \\
\hline 18 & $1.64 \mathrm{E}-06(\mathrm{~W})$ & $7.52 \mathrm{E}-07(\mathrm{G})$ & $4.84 \mathrm{E}-06(\mathrm{~W})$ & $9.27 \mathrm{E}-09(\mathrm{G})$ & $5.74 \mathrm{E}-08(\mathrm{G})$ \\
\hline 19 & $1.73 \mathrm{E}-06(\mathrm{~W})$ & 7.94E-07 (G) & $5.11 \mathrm{E}-06(\mathrm{~W})$ & $9.78 \mathrm{E}-09(\mathrm{G})$ & $6.06 \mathrm{E}-08(\mathrm{G})$ \\
\hline 20 & $1.82 \mathrm{E}-06(\mathrm{~W})$ & $8.36 \mathrm{E}-07(\mathrm{G})$ & 5.38E-06 (W) & $1.03 \mathrm{E}-08(\mathrm{G})$ & $6.38 \mathrm{E}-08(\mathrm{G})$ \\
\hline
\end{tabular}


Some 'Green' or 'White' results derived from the generic CCF multipliers became 'White' or 'Yellow' using the plant-specific CCF multipliers. The results demonstrate that the CCF multiplier is an important element in the MSPI calculation because it decides the value of the CCF adjusted Birnbaum that provides the measure of risk sensitivity of a plant component to CDF. Generally, it was more conservative to use the plant-specific $\mathrm{CCF}$ multipliers than the generic CCF multipliers for these sensitivity results. Nevertheless, some MSPI results remained 'Green' even if a large number of failures occurred.

c) MSPI sensitivity analysis using backstops and plantspecific CCF multipliers

For the final sensitivity analysis, the backstop was applied using the plant-specific CCF multipliers. The backstop values were derived using equations (7) and (8). The MPSI sensitivity results when the supplemental performance threshold was used are presented in Table 24 to Table 27. For all types of NPPs, the MSPI results changed from 'Green' to 'White' before a large number of failures occurred; therefore, the issue of 'insensitive indicators' can be solved to some degree using this supplemental performance threshold. Therefore, the supplemental performance threshold must be added to limit the total number of failures of a component if the MSPI is selected as a safety system performance indicator for Korean NPPs.

\section{EVALUATION OF THE EXISTING SPI THRESHOLDS FOR GRADED INSPECTION}

\subsection{Framework for Establishing PI Thresholds Using Risk-informed Approach}

Determining the PI threshold is generally dependent

Table 15. MSPI Sensitivity Results Using the Generic CCF Multiplier (RHR-MDP)

\begin{tabular}{|c|c|c|c|c|c|}
\hline $\begin{array}{l}\text { Demand Failures in } \\
\text { Three Years }\end{array}$ & WH900 & WH600 & OPR1000 & Framatome & CANDU \\
\hline 0 & $-6.20 \mathrm{E}-09(\mathrm{G})$ & 7.47E-09 (G) & $1.02 \mathrm{E}-08(\mathrm{G})$ & $1.94 \mathrm{E}-10(\mathrm{G})$ & $1.07 \mathrm{E}-08(\mathrm{G})$ \\
\hline 1 & $1.30 \mathrm{E}-07(\mathrm{G})$ & $6.29 \mathrm{E}-08(\mathrm{G})$ & $6.46 \mathrm{E}-08(\mathrm{G})$ & $1.11 \mathrm{E}-09(\mathrm{G})$ & $6.15 \mathrm{E}-08(\mathrm{G})$ \\
\hline 2 & $2.67 \mathrm{E}-07(\mathrm{G})$ & $1.18 \mathrm{E}-07(\mathrm{G})$ & 1.19E-07 (G) & $2.03 \mathrm{E}-09(\mathrm{G})$ & $1.12 \mathrm{E}-07(\mathrm{G})$ \\
\hline 3 & 4.03E-07 (G) & $1.74 \mathrm{E}-07(\mathrm{G})$ & $1.73 \mathrm{E}-07(\mathrm{G})$ & $2.95 \mathrm{E}-09(\mathrm{G})$ & $1.63 \mathrm{E}-07(\mathrm{G})$ \\
\hline 4 & $5.40 \mathrm{E}-07(\mathrm{G})$ & $2.29 \mathrm{E}-07(\mathrm{G})$ & $2.28 \mathrm{E}-07(\mathrm{G})$ & $3.86 \mathrm{E}-09(\mathrm{G})$ & $2.14 \mathrm{E}-07(\mathrm{G})$ \\
\hline 5 & $6.76 \mathrm{E}-07(\mathrm{G})$ & $2.85 \mathrm{E}-07(\mathrm{G})$ & $2.82 \mathrm{E}-07(\mathrm{G})$ & $4.78 \mathrm{E}-09(\mathrm{G})$ & $2.65 \mathrm{E}-07(\mathrm{G})$ \\
\hline 6 & 8.13E-07 (G) & $3.40 \mathrm{E}-07(\mathrm{G})$ & $3.36 \mathrm{E}-07(\mathrm{G})$ & $5.70 \mathrm{E}-09(\mathrm{G})$ & $3.16 \mathrm{E}-07(\mathrm{G})$ \\
\hline 7 & $9.49 \mathrm{E}-07(\mathrm{G})$ & $3.96 \mathrm{E}-07(\mathrm{G})$ & $3.91 \mathrm{E}-07(\mathrm{G})$ & $6.62 \mathrm{E}-09(\mathrm{G})$ & $3.66 \mathrm{E}-07(\mathrm{G})$ \\
\hline 8 & $1.09 \mathrm{E}-06(\mathrm{~W})$ & $4.51 \mathrm{E}-07(\mathrm{G})$ & $4.45 \mathrm{E}-07(\mathrm{G})$ & $7.53 \mathrm{E}-09(\mathrm{G})$ & 4.17E-07 (G) \\
\hline 9 & $1.22 \mathrm{E}-06(\mathrm{~W})$ & $5.06 \mathrm{E}-07(\mathrm{G})$ & 4.99E-07 (G) & $8.45 \mathrm{E}-09(\mathrm{G})$ & $4.68 \mathrm{E}-07(\mathrm{G})$ \\
\hline 10 & $1.36 \mathrm{E}-06(\mathrm{~W})$ & $5.62 \mathrm{E}-07(\mathrm{G})$ & 5.54E-07 (G) & $9.37 \mathrm{E}-09(\mathrm{G})$ & $5.19 \mathrm{E}-07(\mathrm{G})$ \\
\hline 11 & $1.50 \mathrm{E}-06(\mathrm{~W})$ & $6.17 \mathrm{E}-07(\mathrm{G})$ & $6.08 \mathrm{E}-07(\mathrm{G})$ & $1.03 \mathrm{E}-08(\mathrm{G})$ & $5.70 \mathrm{E}-07(\mathrm{G})$ \\
\hline 12 & $1.63 \mathrm{E}-06(\mathrm{~W})$ & $6.73 \mathrm{E}-07(\mathrm{G})$ & $6.63 \mathrm{E}-07(\mathrm{G})$ & $1.12 \mathrm{E}-08(\mathrm{G})$ & $6.20 \mathrm{E}-07(\mathrm{G})$ \\
\hline 13 & $1.77 \mathrm{E}-06(\mathrm{~W})$ & $7.28 \mathrm{E}-07(\mathrm{G})$ & 7.17E-07 (G) & $1.21 \mathrm{E}-08(\mathrm{G})$ & $6.71 \mathrm{E}-07(\mathrm{G})$ \\
\hline 14 & $1.90 \mathrm{E}-06(\mathrm{~W})$ & 7.84E-07 (G) & $7.71 \mathrm{E}-07(\mathrm{G})$ & $1.30 \mathrm{E}-08(\mathrm{G})$ & $7.22 \mathrm{E}-07(\mathrm{G})$ \\
\hline 15 & $2.04 \mathrm{E}-06(\mathrm{~W})$ & $8.39 \mathrm{E}-07(\mathrm{G})$ & $8.26 \mathrm{E}-07(\mathrm{G})$ & $1.40 \mathrm{E}-08(\mathrm{G})$ & $7.73 \mathrm{E}-07(\mathrm{G})$ \\
\hline 16 & $2.18 \mathrm{E}-06(\mathrm{~W})$ & $8.94 \mathrm{E}-07(\mathrm{G})$ & 8.80E-07 (G) & $1.49 \mathrm{E}-08(\mathrm{G})$ & $8.24 \mathrm{E}-07(\mathrm{G})$ \\
\hline 17 & $2.31 \mathrm{E}-06(\mathrm{~W})$ & $9.50 \mathrm{E}-07(\mathrm{G})$ & 9.34E-07 (G) & $1.58 \mathrm{E}-08(\mathrm{G})$ & $8.74 \mathrm{E}-07(\mathrm{G})$ \\
\hline 18 & $2.45 \mathrm{E}-06(\mathrm{~W})$ & $1.01 \mathrm{E}-06(\mathrm{~W})$ & 9.89E-07 (G) & $1.67 \mathrm{E}-08(\mathrm{G})$ & $9.25 \mathrm{E}-07(\mathrm{G})$ \\
\hline 19 & $2.59 \mathrm{E}-06(\mathrm{~W})$ & $1.06 \mathrm{E}-06(\mathrm{~W})$ & $1.04 \mathrm{E}-06(\mathrm{~W})$ & $1.76 \mathrm{E}-08(\mathrm{G})$ & $9.76 \mathrm{E}-07(\mathrm{G})$ \\
\hline 20 & $2.72 \mathrm{E}-06(\mathrm{~W})$ & $1.12 \mathrm{E}-06(\mathrm{~W})$ & $1.10 \mathrm{E}-06(\mathrm{~W})$ & $1.85 \mathrm{E}-08(\mathrm{G})$ & $1.03 \mathrm{E}-06(\mathrm{~W})$ \\
\hline
\end{tabular}


LEE et al., A Feasibility Study on the Advanced Performance Indicator Concept for Improving KINS Safety Performance Indicators (SPI)

Table 16. MSPI Sensitivity Results Using the Generic CCF Multiplier (AFW-MDP)

\begin{tabular}{|c|c|c|c|c|c|}
\hline $\begin{array}{l}\text { Demand Failures in } \\
\text { Three Years }\end{array}$ & WH900 & WH600 & OPR1000 & Framatome & CANDU \\
\hline 0 & $-3.34 \mathrm{E}-08(\mathrm{G})$ & $-1.36 \mathrm{E}-09(\mathrm{G})$ & -8.97E-09(G) & $-4.05 \mathrm{E}-10(\mathrm{G})$ & $-4.30 \mathrm{E}-10(\mathrm{G})$ \\
\hline 1 & $7.01 \mathrm{E}-07(\mathrm{G})$ & $2.86 \mathrm{E}-08(\mathrm{G})$ & $1.88 \mathrm{E}-07(\mathrm{G})$ & $8.51 \mathrm{E}-09(\mathrm{G})$ & $1.86 \mathrm{E}-08(\mathrm{G})$ \\
\hline 2 & $1.43 \mathrm{E}-06(\mathrm{~W})$ & $5.86 \mathrm{E}-08(\mathrm{G})$ & $3.86 \mathrm{E}-07(\mathrm{G})$ & $1.74 \mathrm{E}-08(\mathrm{G})$ & $3.76 \mathrm{E}-08(\mathrm{G})$ \\
\hline 3 & 2.17E-06 (W) & $8.86 \mathrm{E}-08(\mathrm{G})$ & 5.83E-07 (G) & $2.64 \mathrm{E}-08(\mathrm{G})$ & $5.65 \mathrm{E}-08(\mathrm{G})$ \\
\hline 4 & $2.90 \mathrm{E}-06(\mathrm{~W})$ & 1.19E-07 (G) & 7.81E-07 (G) & $3.53 \mathrm{E}-08(\mathrm{G})$ & $7.55 \mathrm{E}-08(\mathrm{G})$ \\
\hline 5 & $3.64 \mathrm{E}-06(\mathrm{~W})$ & $1.49 \mathrm{E}-07(\mathrm{G})$ & $9.78 \mathrm{E}-07(\mathrm{G})$ & $4.42 \mathrm{E}-08(\mathrm{G})$ & $9.45 \mathrm{E}-08(\mathrm{G})$ \\
\hline 6 & 4.37E-06 (W) & 1.79E-07 (G) & $1.18 \mathrm{E}-06(\mathrm{~W})$ & $5.31 \mathrm{E}-08(\mathrm{G})$ & $1.14 \mathrm{E}-07(\mathrm{G})$ \\
\hline 7 & $5.10 \mathrm{E}-06(\mathrm{~W})$ & $2.09 \mathrm{E}-07(\mathrm{G})$ & $1.37 \mathrm{E}-06(\mathrm{~W})$ & $6.20 \mathrm{E}-08(\mathrm{G})$ & $1.33 \mathrm{E}-07(\mathrm{G})$ \\
\hline 8 & $5.84 \mathrm{E}-06(\mathrm{~W})$ & $2.39 \mathrm{E}-07(\mathrm{G})$ & $1.57 \mathrm{E}-06(\mathrm{~W})$ & $7.10 \mathrm{E}-08(\mathrm{G})$ & $1.51 \mathrm{E}-07(\mathrm{G})$ \\
\hline 9 & $6.57 \mathrm{E}-06(\mathrm{~W})$ & $2.69 \mathrm{E}-07(\mathrm{G})$ & $1.77 \mathrm{E}-06(\mathrm{~W})$ & 7.99E-08 (G) & $1.70 \mathrm{E}-07(\mathrm{G})$ \\
\hline 10 & 7.31E-06 (W) & 2.99E-07 (G) & $1.96 \mathrm{E}-06(\mathrm{~W})$ & $8.88 \mathrm{E}-08(\mathrm{G})$ & $1.89 \mathrm{E}-07(\mathrm{G})$ \\
\hline 11 & 8.04E-06 (W) & $3.29 \mathrm{E}-07(\mathrm{G})$ & $2.16 \mathrm{E}-06(\mathrm{~W})$ & $9.77 \mathrm{E}-08(\mathrm{G})$ & $2.08 \mathrm{E}-07(\mathrm{G})$ \\
\hline 12 & $8.77 \mathrm{E}-06(\mathrm{~W})$ & $3.59 \mathrm{E}-07(\mathrm{G})$ & $2.36 \mathrm{E}-06(\mathrm{~W})$ & $1.07 \mathrm{E}-07(\mathrm{G})$ & $2.27 \mathrm{E}-07(\mathrm{G})$ \\
\hline 13 & $9.51 \mathrm{E}-06(\mathrm{~W})$ & 3.89E-07 (G) & $2.56 \mathrm{E}-06(\mathrm{~W})$ & $1.16 \mathrm{E}-07(\mathrm{G})$ & $2.46 \mathrm{E}-07(\mathrm{G})$ \\
\hline 14 & $1.02 \mathrm{E}-05(\mathrm{Y})$ & 4.19E-07 (G) & $2.75 \mathrm{E}-06(\mathrm{~W})$ & $1.24 \mathrm{E}-07(\mathrm{G})$ & $2.65 \mathrm{E}-07(\mathrm{G})$ \\
\hline 15 & $1.10 \mathrm{E}-05(\mathrm{Y})$ & 4.49E-07 (G) & $2.95 \mathrm{E}-06(\mathrm{~W})$ & $1.33 \mathrm{E}-07(\mathrm{G})$ & $2.84 \mathrm{E}-07(\mathrm{G})$ \\
\hline 16 & $1.17 \mathrm{E}-05(\mathrm{Y})$ & 4.79E-07 (G) & $3.15 \mathrm{E}-06(\mathrm{~W})$ & $1.42 \mathrm{E}-07(\mathrm{G})$ & $3.03 \mathrm{E}-07(\mathrm{G})$ \\
\hline 17 & $1.24 \mathrm{E}-05(\mathrm{Y})$ & 5.09E-07 (G) & $3.35 \mathrm{E}-06(\mathrm{~W})$ & $1.51 \mathrm{E}-07(\mathrm{G})$ & $3.22 \mathrm{E}-07(\mathrm{G})$ \\
\hline 18 & $1.32 \mathrm{E}-05(\mathrm{Y})$ & 5.38E-07 (G) & $3.54 \mathrm{E}-06(\mathrm{~W})$ & $1.60 \mathrm{E}-07(\mathrm{G})$ & $3.41 \mathrm{E}-07(\mathrm{G})$ \\
\hline 19 & $1.39 \mathrm{E}-05(\mathrm{Y})$ & $5.68 \mathrm{E}-07(\mathrm{G})$ & $3.74 \mathrm{E}-06(\mathrm{~W})$ & $1.69 \mathrm{E}-07(\mathrm{G})$ & $3.60 \mathrm{E}-07(\mathrm{G})$ \\
\hline 20 & $1.46 \mathrm{E}-05(\mathrm{Y})$ & $5.98 \mathrm{E}-07(\mathrm{G})$ & 3.94E-06 (W) & $1.78 \mathrm{E}-07(\mathrm{G})$ & 3.79E-07 (G) \\
\hline
\end{tabular}

Table 17. LOOP Frequencies Modeled in the Licensee PSA Models for the Five Types of Korean NPPs

\begin{tabular}{c|c|c|c|c|c}
\hline Event Name & WH900 & WH600 & OPR1000 & Framatome & CANDU \\
\hline LOOP $(/ \mathrm{yr})$ & $2.41 \mathrm{E}-02$ & $4.27 \mathrm{E}-02$ & $2.20 \mathrm{E}-02$ & $4.64 \mathrm{E}-02$ & $6.14 \mathrm{E}-02$ \\
\hline
\end{tabular}

Table 18. Plant-Specific CCF Multipliers for Demand Failure of Pumps and Diesel Generators Derived By Using PSA Results of Korean NPPs

\begin{tabular}{c|c|c|c|c|c}
\hline System-Component & WH900 & WH600 & OPR1000 & Framatome & CANDU \\
\hline EAC-EDG & 1.86 & 2.08 & 1.87 & 2.09 & 1.22 \\
\hline HPSI-MDP & 1.14 & 4.56 & 6.48 & 8.74 & 7.83 \\
\hline RHR-MDP & 4.07 & 3.63 & $5.15 / 4.57^{16}$ & 4.40 & 1.00 \\
\hline AF-MDP & 1.40 & 2.50 & 1.41 & 45 \\
\hline
\end{tabular}


on the PI users' philosophy for usage. Some existing SPI thresholds in KINS are based on the corresponding values of the ROP PI threshold in the USNRC, albeit with slight modifications. The SPI system in KINS has not yet been used in the formal regulatory decision processes because the existing regulatory inspection

Table 19. Highest CCF Adjusted Birnbaums for Demand Failure of Pumps and Diesel Generators Using the Plant-Specific CCF Multipliers

\begin{tabular}{c|c|c|c|c|c}
\hline System-Component & WH900 & WH600 & OPR1000 & Framatome & CANDU \\
\hline EAC-EDG & $1.16 \mathrm{E}-04$ & $5.87 \mathrm{E}-05$ & $7.33 \mathrm{E}-06$ & $2.70 \mathrm{E}-04$ & $9.49 \mathrm{E}-06$ \\
\hline HPSI-MDP & $5.01 \mathrm{E}-07$ & $1.00 \mathrm{E}-05$ & $8.96 \mathrm{E}-05$ & $1.77 \mathrm{E}-07$ & $2.02 \mathrm{E}-06$ \\
\hline RHR-MDP & $2.53 \mathrm{E}-05$ & $2.59 \mathrm{E}-05$ & $2.04 \mathrm{E}-05$ & $1.53 \mathrm{E}-06$ & $7.05 \mathrm{E}-06$ \\
\hline AF-MDP & $6.54 \mathrm{E}-05$ & $8.81 \mathrm{E}-06$ & $5.86 \mathrm{E}-05$ & $5.31 \mathrm{E}-06$ & $5.19 \mathrm{E}-06$ \\
\hline
\end{tabular}

Table 20. MSPI Sensitivity Results Using the Plant-Specific CCF Multiplier (EAC-EDG) ${ }^{17}$

\begin{tabular}{|c|c|c|c|c|c|}
\hline $\begin{array}{c}\text { Demand Failures in } \\
\text { Three Years }\end{array}$ & WH900 & WH600 & OPR1000 & Framatome & CANDU \\
\hline 0 & $-8.31 \mathrm{E}-08(\mathrm{G})$ & $-1.42 \mathrm{E}-07(\mathrm{G})$ & $-3.09 \mathrm{E}-08(\mathrm{G})$ & $-1.07 \mathrm{E}-06(\mathrm{G})$ & $-3.72 \mathrm{E}-08(\mathrm{G})$ \\
\hline 1 & $1.48 \mathrm{E}-07(\mathrm{G})$ & $2.53 \mathrm{E}-07(\mathrm{G})$ & 5.49E-08 (G) & $1.90 \mathrm{E}-06(\mathrm{~W})$ & $6.61 \mathrm{E}-08(\mathrm{G})$ \\
\hline 2 & $3.78 \mathrm{E}-07(\mathrm{G})$ & $6.49 \mathrm{E}-07(\mathrm{G})$ & $1.41 \mathrm{E}-07(\mathrm{G})$ & $4.88 \mathrm{E}-06(\mathrm{~W})$ & $1.69 \mathrm{E}-07(\mathrm{G})$ \\
\hline 3 & 6.09E-07 (G) & $1.04 \mathrm{E}-06(\mathrm{~W})$ & $2.26 \mathrm{E}-07(\mathrm{G})$ & $7.85 \mathrm{E}-06(\mathrm{~W})$ & $2.73 \mathrm{E}-07(\mathrm{G})$ \\
\hline 4 & $8.40 \mathrm{E}-07(\mathrm{G})$ & $1.44 \mathrm{E}-06(\mathrm{~W})$ & $3.12 \mathrm{E}-07(\mathrm{G})$ & $1.08 \mathrm{E}-05(\mathrm{Y})$ & $3.76 \mathrm{E}-07(\mathrm{G})$ \\
\hline 5 & $1.07 \mathrm{E}-06(\mathrm{~W})$ & $1.84 \mathrm{E}-06(\mathrm{~W})$ & $3.98 \mathrm{E}-07(\mathrm{G})$ & $1.38 \mathrm{E}-05(\mathrm{Y})$ & 4.79E-07 (G) \\
\hline 6 & $1.30 \mathrm{E}-06(\mathrm{~W})$ & $2.23 \mathrm{E}-06(\mathrm{~W})$ & 4.83E-07 (G) & $1.68 \mathrm{E}-05(\mathrm{Y})$ & $5.82 \mathrm{E}-07(\mathrm{G})$ \\
\hline 7 & $1.53 \mathrm{E}-06(\mathrm{~W})$ & $2.63 \mathrm{E}-06(\mathrm{~W})$ & 5.69E-07 (G) & $1.98 \mathrm{E}-05(\mathrm{Y})$ & $6.86 \mathrm{E}-07(\mathrm{G})$ \\
\hline 8 & $1.76 \mathrm{E}-06(\mathrm{~W})$ & $3.02 \mathrm{E}-06(\mathrm{~W})$ & $6.55 \mathrm{E}-07(\mathrm{G})$ & $2.27 \mathrm{E}-05(\mathrm{Y})$ & 7.89E-07 (G) \\
\hline 9 & 1.99E-06 (W) & $3.42 \mathrm{E}-06(\mathrm{~W})$ & 7.41E-07 (G) & $2.57 \mathrm{E}-05(\mathrm{Y})$ & $8.92 \mathrm{E}-07(\mathrm{G})$ \\
\hline 10 & $2.22 \mathrm{E}-06(\mathrm{~W})$ & $3.82 \mathrm{E}-06(\mathrm{~W})$ & $8.26 \mathrm{E}-07(\mathrm{G})$ & 2.87E-05 (Y) & $9.95 \mathrm{E}-07(\mathrm{G})$ \\
\hline 11 & $2.46 \mathrm{E}-06(\mathrm{~W})$ & $4.21 \mathrm{E}-06(\mathrm{~W})$ & $9.12 \mathrm{E}-07(\mathrm{G})$ & 3.17E-05 (Y) & $1.10 \mathrm{E}-06(\mathrm{~W})$ \\
\hline 12 & 2.69E-06 (W) & 4.61E-06 (W) & 9.98E-07 (G) & $3.46 \mathrm{E}-05(\mathrm{Y})$ & $1.20 \mathrm{E}-06(\mathrm{~W})$ \\
\hline 13 & $2.92 \mathrm{E}-06(\mathrm{~W})$ & $5.00 \mathrm{E}-06(\mathrm{~W})$ & $1.08 \mathrm{E}-06(\mathrm{~W})$ & $3.76 \mathrm{E}-05(\mathrm{Y})$ & $1.30 \mathrm{E}-06(\mathrm{~W})$ \\
\hline 14 & $3.15 \mathrm{E}-06(\mathrm{~W})$ & $5.40 \mathrm{E}-06(\mathrm{~W})$ & $1.17 \mathrm{E}-06(\mathrm{~W})$ & $4.06 \mathrm{E}-05(\mathrm{Y})$ & $1.41 \mathrm{E}-06(\mathrm{~W})$ \\
\hline 15 & $3.38 \mathrm{E}-06(\mathrm{~W})$ & $5.79 \mathrm{E}-06(\mathrm{~W})$ & $1.25 \mathrm{E}-06(\mathrm{~W})$ & 4.35E-05 (Y) & $1.51 \mathrm{E}-06(\mathrm{~W})$ \\
\hline 16 & $3.61 \mathrm{E}-06(\mathrm{~W})$ & $6.19 \mathrm{E}-06(\mathrm{~W})$ & $1.34 \mathrm{E}-06(\mathrm{~W})$ & 4.65E-05 (Y) & $1.61 \mathrm{E}-06(\mathrm{~W})$ \\
\hline 17 & $3.84 \mathrm{E}-06(\mathrm{~W})$ & $6.59 \mathrm{E}-06(\mathrm{~W})$ & $1.43 \mathrm{E}-06(\mathrm{~W})$ & 4.95E-05 (Y) & $1.72 \mathrm{E}-06(\mathrm{~W})$ \\
\hline 18 & 4.07E-06 (W) & $6.98 \mathrm{E}-06(\mathrm{~W})$ & $1.51 \mathrm{E}-06(\mathrm{~W})$ & $5.25 \mathrm{E}-05(\mathrm{Y})$ & $1.82 \mathrm{E}-06(\mathrm{~W})$ \\
\hline 19 & $4.30 \mathrm{E}-06(\mathrm{~W})$ & $7.38 \mathrm{E}-06(\mathrm{~W})$ & $1.60 \mathrm{E}-06(\mathrm{~W})$ & $5.54 \mathrm{E}-05(\mathrm{Y})$ & $1.92 \mathrm{E}-06(\mathrm{~W})$ \\
\hline 20 & $4.53 \mathrm{E}-06(\mathrm{~W})$ & $7.77 \mathrm{E}-06(\mathrm{~W})$ & $1.68 \mathrm{E}-06(\mathrm{~W})$ & $5.84 \mathrm{E}-05(\mathrm{Y})$ & $2.03 \mathrm{E}-06(\mathrm{~W})$ \\
\hline
\end{tabular}

${ }^{16}$ For OPR1000, containment spray (CS) pumps as well as shutdown cooling (SC) pumps are used for residual heat removal function. Therefore, the CCF multipliers are derived for the CS pumps and SC pumps.

${ }^{17}(\mathrm{G})$ - Green, (W) - White, (Y) - Yellow 
program in Korea does not include a graded approach based on the safety grade of each NPP. However, the PI system is used to determine the safety grade of each NPP and for graded inspection in the USNRC.

As stated previously, the development of an ISPA program for improving the existing regulatory inspection system using the results of the PSA and safety performance assessment is in progress at KINS. In the ISPA program, graded inspection will be implemented and PIs will be the one of the main components in determining the safety grade of each NPP. Therefore, it is necessary to examine the existing SPI threshold for use in the graded inspection program in Korea.

In the graded inspection program, the PI thresholds must be defined considering the risk and regulatory responses to different levels of licensee performance. Moreover, the PI thresholds must be consistent with other risk-informed regulatory applications and policies, as well as consistent with the regulatory requirements and limits. In the USNRC, the conceptual framework for establishing PI thresholds using a risk-informed approach has been developed as presented in Figure 1 and was used to establish the ROP PI thresholds [15]. The conceptual framework has both a probabilistic basis and a deterministic basis. The historical data or delta CDF was used as the probabilistic basis, and the safety parameters in the technical specifications (TS), the concept of safety margins, or expert judgment were used as the deterministic basis in establishing general ROP PI thresholds. Because the PI thresholds must be consistent with other risk-informed regulatory applications, the delta CDF thresholds used in the PI were determined based on regulatory guide 1.174 [16] and the subsidiary CDF objective ${ }^{7}$ [17] of the USNRC. The brief implication of each performance band

Table 21. MSPI Sensitivity Results Using the Plant-Specific CCF Multiplier (HPSI-MDP)

\begin{tabular}{|c|c|c|c|c|c|}
\hline $\begin{array}{l}\text { Demand Failures in } \\
\text { Three Years }\end{array}$ & WH900 & WH600 & OPR1000 & Framatome & CANDU \\
\hline 0 & $-2.61 \mathrm{E}-09(\mathrm{G})$ & $-2.89 \mathrm{E}-09(\mathrm{G})$ & $-2.65 \mathrm{E}-08(\mathrm{G})$ & $-8.66 \mathrm{E}-12(\mathrm{G})$ & $-3.79 \mathrm{E}-10(\mathrm{G})$ \\
\hline 1 & $6.90 \mathrm{E}-08(\mathrm{G})$ & $6.08 \mathrm{E}-08(\mathrm{G})$ & 5.56E-07 (G) & $3.45 \mathrm{E}-10(\mathrm{G})$ & $7.96 \mathrm{E}-09(\mathrm{G})$ \\
\hline 2 & $1.41 \mathrm{E}-07(\mathrm{G})$ & $1.24 \mathrm{E}-07(\mathrm{G})$ & $1.14 \mathrm{E}-06(\mathrm{~W})$ & $6.98 \mathrm{E}-10(\mathrm{G})$ & $1.63 \mathrm{E}-08(\mathrm{G})$ \\
\hline 3 & 2.12E-07 (G) & $1.88 \mathrm{E}-07(\mathrm{G})$ & $1.72 \mathrm{E}-06(\mathrm{~W})$ & $1.05 \mathrm{E}-09(\mathrm{G})$ & $2.47 \mathrm{E}-08(\mathrm{G})$ \\
\hline 4 & 2.84E-07 (G) & $2.52 \mathrm{E}-07(\mathrm{G})$ & $2.30 \mathrm{E}-06(\mathrm{~W})$ & $1.41 \mathrm{E}-09(\mathrm{G})$ & $3.30 \mathrm{E}-08(\mathrm{G})$ \\
\hline 5 & $3.55 \mathrm{E}-07(\mathrm{G})$ & $3.15 \mathrm{E}-07$ (G) & $2.89 \mathrm{E}-06(\mathrm{~W})$ & $1.76 \mathrm{E}-09(\mathrm{G})$ & $4.13 \mathrm{E}-08(\mathrm{G})$ \\
\hline 6 & 4.27E-07 (G) & 3.79E-07 (G) & $3.47 \mathrm{E}-06(\mathrm{~W})$ & $2.11 \mathrm{E}-09(\mathrm{G})$ & 4.97E-08 (G) \\
\hline 7 & 4.98E-07 (G) & 4.43E-07 (G) & $4.05 \mathrm{E}-06(\mathrm{~W})$ & 2.47E-09 (G) & $5.80 \mathrm{E}-08(\mathrm{G})$ \\
\hline 8 & 5.70E-07 (G) & 5.07E-07 (G) & 4.63E-06 (W) & 2.82E-09 (G) & $6.64 \mathrm{E}-08(\mathrm{G})$ \\
\hline 9 & $6.42 \mathrm{E}-07(\mathrm{G})$ & 5.70E-07 (G) & $5.22 \mathrm{E}-06(\mathrm{~W})$ & 3.17E-09 (G) & 7.47E-08 (G) \\
\hline 10 & 7.13E-07 (G) & $6.34 \mathrm{E}-07(\mathrm{G})$ & $5.80 \mathrm{E}-06(\mathrm{~W})$ & $3.53 \mathrm{E}-09(\mathrm{G})$ & $8.31 \mathrm{E}-08(\mathrm{G})$ \\
\hline 11 & 7.85E-07 (G) & $6.98 \mathrm{E}-07(\mathrm{G})$ & $6.38 \mathrm{E}-06(\mathrm{~W})$ & 3.88E-09 (G) & $9.14 \mathrm{E}-08(\mathrm{G})$ \\
\hline 12 & 8.56E-07 (G) & $7.61 \mathrm{E}-07$ (G) & $6.96 \mathrm{E}-06(\mathrm{~W})$ & 4.23E-09 (G) & 9.97E-08 (G) \\
\hline 13 & $9.28 \mathrm{E}-07(\mathrm{G})$ & $8.25 \mathrm{E}-07(\mathrm{G})$ & $7.55 \mathrm{E}-06(\mathrm{~W})$ & 4.59E-09 (G) & $1.08 \mathrm{E}-07(\mathrm{G})$ \\
\hline 14 & $1.00 \mathrm{E}-06(\mathrm{~W})$ & 8.89E-07 (G) & $8.13 \mathrm{E}-06(\mathrm{~W})$ & 4.94E-09 (G) & $1.16 \mathrm{E}-07(\mathrm{G})$ \\
\hline 15 & $1.07 \mathrm{E}-06(\mathrm{~W})$ & 9.52E-07 (G) & 8.71E-06 (W) & 5.29E-09 (G) & $1.25 \mathrm{E}-07(\mathrm{G})$ \\
\hline 16 & $1.14 \mathrm{E}-06(\mathrm{~W})$ & $1.02 \mathrm{E}-06(\mathrm{~W})$ & $9.30 \mathrm{E}-06(\mathrm{~W})$ & $5.65 \mathrm{E}-09(\mathrm{G})$ & $1.33 \mathrm{E}-07(\mathrm{G})$ \\
\hline 17 & $1.21 \mathrm{E}-06(\mathrm{~W})$ & $1.08 \mathrm{E}-06(\mathrm{~W})$ & $9.88 \mathrm{E}-06(\mathrm{~W})$ & $6.00 \mathrm{E}-09(\mathrm{G})$ & $1.41 \mathrm{E}-07(\mathrm{G})$ \\
\hline 18 & $1.29 \mathrm{E}-06(\mathrm{~W})$ & $1.14 \mathrm{E}-06(\mathrm{~W})$ & $1.05 \mathrm{E}-05(\mathrm{Y})$ & $6.36 \mathrm{E}-09(\mathrm{G})$ & $1.50 \mathrm{E}-07(\mathrm{G})$ \\
\hline 19 & $1.36 \mathrm{E}-06(\mathrm{~W})$ & $1.21 \mathrm{E}-06(\mathrm{~W})$ & $1.10 \mathrm{E}-05(\mathrm{Y})$ & $6.71 \mathrm{E}-09(\mathrm{G})$ & $1.58 \mathrm{E}-07(\mathrm{G})$ \\
\hline 20 & $1.43 \mathrm{E}-06(\mathrm{~W})$ & $1.27 \mathrm{E}-06(\mathrm{~W})$ & $1.16 \mathrm{E}-05(\mathrm{Y})$ & $7.06 \mathrm{E}-09(\mathrm{G})$ & $1.66 \mathrm{E}-07(\mathrm{G})$ \\
\hline
\end{tabular}


is presented in Table 28. A detailed explanation of the implications of the conceptual framework follows.

- The 'Green' band presented in Figure 1 is characterized by acceptable performance in which the cornerstone objectives are fully met, the performance value is within the expected range, and the delta CDF is below $1.0 \mathrm{E}-6 / \mathrm{yr}$. The licensees in this band have maximum flexibility for NPP operation.

- The 'White' band is entered when licensee performance is outside the normal performance range, but still represents an acceptable level of performance. Performance is still considered to be within the objectives of the cornerstone and is within TS limits, but there is an indication of declining performance and a reduced safety margin. For the CDF, the delta $\mathrm{CDF}$ is higher than $1.0 \mathrm{E}-6 / \mathrm{yr}$ but below $1.0 \mathrm{E}-5 / \mathrm{yr}$ in this range. The CDF threshold characteristics were selected to be consistent with regulatory guide 1.174 applications.

- The 'Yellow' band is entered when there is a more significant decline in performance than the 'White' band, but the licensee performance is still considered acceptable. When TS limits are reached or exceeded, licensees are required to take immediate and effective corrective actions to maintain performance within this band. In terms of the CDF, the delta CDF is higher than $1.0 \mathrm{E}-5 / \mathrm{yr}$ but below $1.0 \mathrm{E}-4 / \mathrm{yr}$.

- The 'Red' band is entered when the performance falls below the 'Yellow' band threshold. This band is an unacceptable performance band. In terms of the CDF, the delta CDF is higher than $1.0 \mathrm{E}-4 / \mathrm{yr}$, which is

${ }^{7}$ The subsidiary CDF objective $1.0 \mathrm{E}-4 / \mathrm{yr}$ is being used in the USNRC, however it has not yet been officially endorsed. determined based on the subsidiary CDF objective. The plant performance is considered to be significantly outside the design basis with an unacceptable margin to safety; further decline in performance would result in operation in a state inconsistent with the specified safety goals.

In Korea, the acceptance guideline for CDF has been officially endorsed by the government and published as KINS-GT-N24 [18], as presented in Figure 2 for riskinformed regulatory decision making. The delta CDF thresholds in KINS-GT-N24 are the same as those in regulatory guide 1.174 , if the baseline CDF of each NPP is higher than $1.0 \mathrm{E}-6 / \mathrm{yr}$. Because all operating NPPs in Korea have a CDF higher than 1.0E-6/yr, the delta CDF thresholds in regulatory guide 1.174 can be also applied to Korean NPPs. However, the subsidiary CDF objective in Korea has not yet been officially finalized.

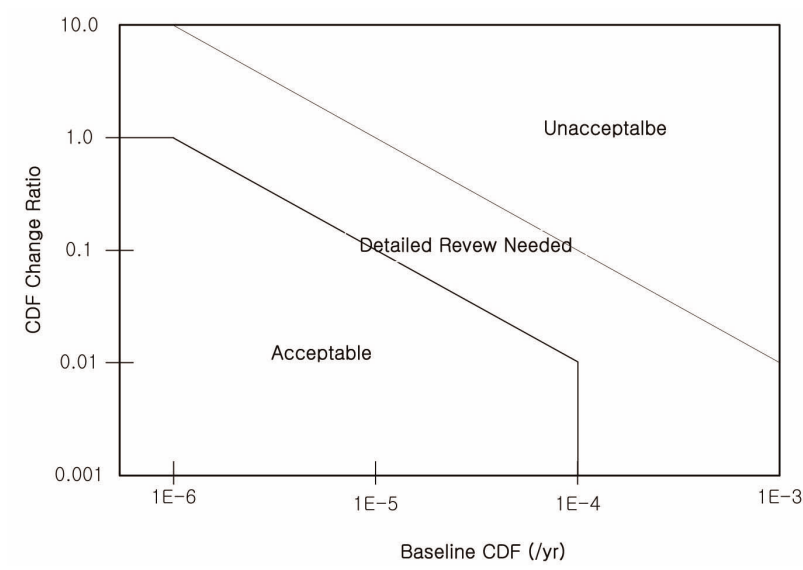

Fig. 2. Conceptual Framework for Setting Performance Thresholds
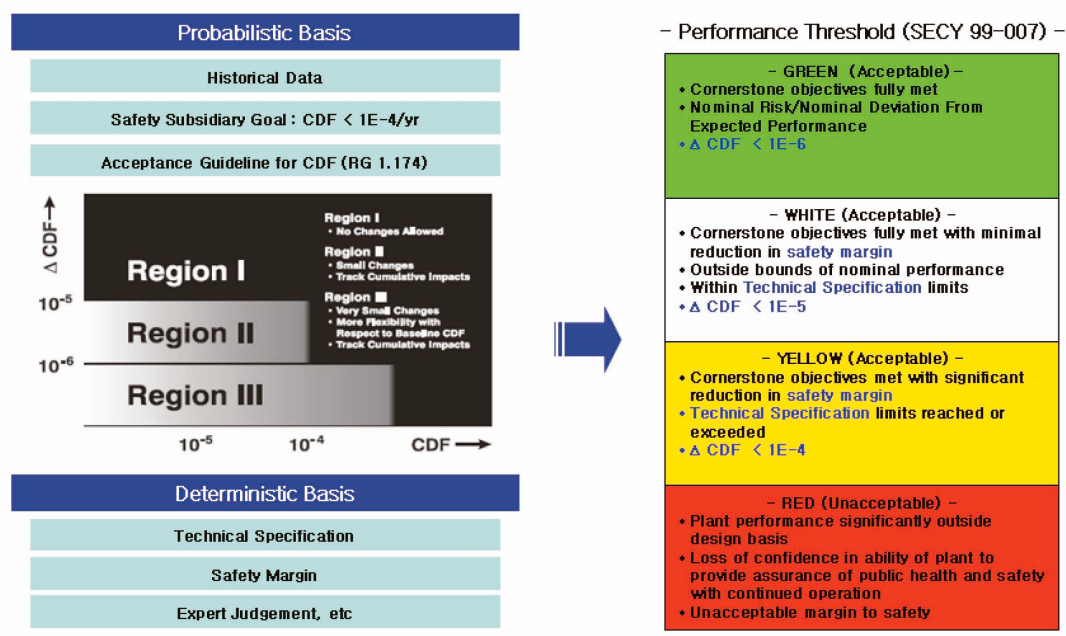

Fig. 1. Conceptual Framework for Setting Performance Thresholds 
Nevertheless, 1.0E-4/yr, which is the same as the interim subsidiary CDF objective of the USNRC [16], has been suggested in a recent draft report prepared by KINS [19]. Therefore, it can be stated that the delta CDF thresholds used in the USNRC PI system can also be applied to the KINS SPI system.

However, the existing KINS SPI system has different implications in the performance bands as presented in Table 29. If the delta CDF thresholds described above are applied to the KINS SPI system, the implications of the performance band of the KINS SPI system should be changed. For example, the worst performance band is 'Orange' in the existing KINS SPI system and 'Red' in the USNRC PI system. The implication of 'Orange' is 'Warning' which means degraded but acceptable performance. However, the implication of 'Red' is 'Unacceptable' which indicates a significantly degraded and unacceptable performance. If the delta CDF threshold is defined as $1.0 \mathrm{E}-4 / \mathrm{yr}$ for the worst performance band in the KINS SPI system, the NPP in this band should be considered as having an unacceptable margin to safety. Therefore 'Orange' in the existing KINS SPI system must be replaced by 'Red' if the delta CDF thresholds are applied to the KINS SPI system. Likewise, the remaining performance band colors and their implications in the existing KINS SPI system as presented in Table 29 must be replaced by those of the USNRC PI system described in Table 28 and Figure 1.

The thresholds of the existing KINS SPIs in the reactor safety area, particularly in the operational safety, and the multiple barrier category presented in Table 1 have been evaluated in this study. The thresholds of the SSU in the safety system category were evaluated because this paper recommends that the existing SSU indicator be replaced by MSPI. Because the delta CDF values are used as the MSPI thresholds, the evaluation of the MSPI thresholds

Table 22. MSPI Sensitivity Results Using the Plant-Specific CCF Multiplier (RHR-MDP)

\begin{tabular}{|c|c|c|c|c|c|}
\hline $\begin{array}{c}\text { Demand Failures in } \\
\text { Three Years }\end{array}$ & WH900 & WH600 & OPR1000 & Framatome & CANDU \\
\hline 0 & $-1.08 \mathrm{E}-08(\mathrm{G})$ & $1.81 \mathrm{E}-08(\mathrm{G})$ & $3.19 \mathrm{E}-08(\mathrm{G})$ & $1.13 \mathrm{E}-09(\mathrm{G})$ & $1.04 \mathrm{E}-08(\mathrm{G})$ \\
\hline 1 & 2.27E-07 (G) & $1.52 \mathrm{E}-07(\mathrm{G})$ & $2.02 \mathrm{E}-07(\mathrm{G})$ & $6.48 \mathrm{E}-09(\mathrm{G})$ & $5.96 \mathrm{E}-08(\mathrm{G})$ \\
\hline 2 & 4.64E-07 (G) & $2.87 \mathrm{E}-07(\mathrm{G})$ & $3.72 \mathrm{E}-07(\mathrm{G})$ & $1.18 \mathrm{E}-08(\mathrm{G})$ & $1.09 \mathrm{E}-07(\mathrm{G})$ \\
\hline 3 & $7.01 \mathrm{E}-07(\mathrm{G})$ & $4.21 \mathrm{E}-07(\mathrm{G})$ & $5.43 \mathrm{E}-07(\mathrm{G})$ & $1.72 \mathrm{E}-08(\mathrm{G})$ & $1.58 \mathrm{E}-07(\mathrm{G})$ \\
\hline 4 & 9.39E-07 (G) & $5.55 \mathrm{E}-07(\mathrm{G})$ & 7.13E-07 (G) & $2.25 \mathrm{E}-08(\mathrm{G})$ & $2.07 \mathrm{E}-07(\mathrm{G})$ \\
\hline 5 & $1.18 \mathrm{E}-06(\mathrm{~W})$ & $6.90 \mathrm{E}-07(\mathrm{G})$ & $8.83 \mathrm{E}-07(\mathrm{G})$ & $2.79 \mathrm{E}-08(\mathrm{G})$ & $2.56 \mathrm{E}-07(\mathrm{G})$ \\
\hline 6 & $1.41 \mathrm{E}-06(\mathrm{~W})$ & $8.24 \mathrm{E}-07(\mathrm{G})$ & $1.05 \mathrm{E}-06(\mathrm{~W})$ & $3.32 \mathrm{E}-08(\mathrm{G})$ & $3.06 \mathrm{E}-07(\mathrm{G})$ \\
\hline 7 & $1.65 \mathrm{E}-06(\mathrm{~W})$ & $9.58 \mathrm{E}-07(\mathrm{G})$ & $1.22 \mathrm{E}-06(\mathrm{~W})$ & $3.86 \mathrm{E}-08(\mathrm{G})$ & $3.55 \mathrm{E}-07(\mathrm{G})$ \\
\hline 8 & $1.89 \mathrm{E}-06(\mathrm{~W})$ & $1.09 \mathrm{E}-06(\mathrm{~W})$ & $1.39 \mathrm{E}-06(\mathrm{~W})$ & 4.39E-08 (G) & 4.04E-07 (G) \\
\hline 9 & $2.13 \mathrm{E}-06(\mathrm{~W})$ & $1.23 \mathrm{E}-06(\mathrm{~W})$ & $1.56 \mathrm{E}-06(\mathrm{~W})$ & $4.93 \mathrm{E}-08(\mathrm{G})$ & $4.53 \mathrm{E}-07(\mathrm{G})$ \\
\hline 10 & $2.36 \mathrm{E}-06(\mathrm{~W})$ & $1.36 \mathrm{E}-06(\mathrm{~W})$ & $1.73 \mathrm{E}-06(\mathrm{~W})$ & $5.46 \mathrm{E}-08(\mathrm{G})$ & $5.02 \mathrm{E}-07(\mathrm{G})$ \\
\hline 11 & $2.60 \mathrm{E}-06(\mathrm{~W})$ & $1.50 \mathrm{E}-06(\mathrm{~W})$ & $1.90 \mathrm{E}-06(\mathrm{~W})$ & $5.99 \mathrm{E}-08(\mathrm{G})$ & $5.51 \mathrm{E}-07(\mathrm{G})$ \\
\hline 12 & $2.84 \mathrm{E}-06(\mathrm{~W})$ & $1.63 \mathrm{E}-06(\mathrm{~W})$ & $2.07 \mathrm{E}-06(\mathrm{~W})$ & $6.53 \mathrm{E}-08(\mathrm{G})$ & $6.01 \mathrm{E}-07(\mathrm{G})$ \\
\hline 13 & $3.07 \mathrm{E}-06(\mathrm{~W})$ & $1.76 \mathrm{E}-06(\mathrm{~W})$ & $2.24 \mathrm{E}-06(\mathrm{~W})$ & $7.06 \mathrm{E}-08(\mathrm{G})$ & $6.50 \mathrm{E}-07(\mathrm{G})$ \\
\hline 14 & $3.31 \mathrm{E}-06(\mathrm{~W})$ & $1.90 \mathrm{E}-06(\mathrm{~W})$ & $2.42 \mathrm{E}-06(\mathrm{~W})$ & $7.60 \mathrm{E}-08(\mathrm{G})$ & $6.99 \mathrm{E}-07(\mathrm{G})$ \\
\hline 15 & $3.55 \mathrm{E}-06(\mathrm{~W})$ & $2.03 \mathrm{E}-06(\mathrm{~W})$ & $2.59 \mathrm{E}-06(\mathrm{~W})$ & $8.13 \mathrm{E}-08(\mathrm{G})$ & $7.48 \mathrm{E}-07(\mathrm{G})$ \\
\hline 16 & $3.79 \mathrm{E}-06(\mathrm{~W})$ & $2.17 \mathrm{E}-06(\mathrm{~W})$ & $2.76 \mathrm{E}-06(\mathrm{~W})$ & $8.67 \mathrm{E}-08(\mathrm{G})$ & 7.97E-07 (G) \\
\hline 17 & $4.02 \mathrm{E}-06(\mathrm{~W})$ & $2.30 \mathrm{E}-06(\mathrm{~W})$ & $2.93 \mathrm{E}-06(\mathrm{~W})$ & $9.20 \mathrm{E}-08(\mathrm{G})$ & $8.47 \mathrm{E}-07(\mathrm{G})$ \\
\hline 18 & $4.26 \mathrm{E}-06(\mathrm{~W})$ & $2.44 \mathrm{E}-06(\mathrm{~W})$ & $3.10 \mathrm{E}-06(\mathrm{~W})$ & $9.74 \mathrm{E}-08(\mathrm{G})$ & $8.96 \mathrm{E}-07(\mathrm{G})$ \\
\hline 19 & $4.50 \mathrm{E}-06(\mathrm{~W})$ & $2.57 \mathrm{E}-06(\mathrm{~W})$ & $3.27 \mathrm{E}-06(\mathrm{~W})$ & $1.03 \mathrm{E}-07(\mathrm{G})$ & $9.45 \mathrm{E}-07(\mathrm{G})$ \\
\hline 20 & $4.74 \mathrm{E}-06(\mathrm{~W})$ & $2.70 \mathrm{E}-06(\mathrm{~W})$ & $3.44 \mathrm{E}-06(\mathrm{~W})$ & $1.08 \mathrm{E}-07(\mathrm{G})$ & 9.94E-07 (G) \\
\hline
\end{tabular}


is not necessary.

The PSA results are used in this paper to evaluate the thresholds of the URS SPI because there is a direct relationship between the URS and parameters in the PSA models, namely the frequency of the initiating events. Qualitative evaluation has been only performed for other SPIs in this paper, which are the Unplanned Power Reduction (UPR) SPI and all SPIs in the multiple barrier category, because they cannot be directly tied to the PSA results.

\subsection{Evaluation of the URS thresholds in KINS SPI}

The existing KINS SPI thresholds for the URS were evaluated using recent domestic PSA results. Previously, a pilot study was undertaken by Kang et al. [20] to estimate the URS thresholds using the domestic PSA results of two reactor types. However, they could not form overall conclusions for the URS thresholds because only two PSA results were used; instead, they revealed that the PSA models for other reactor types must be used to establish the PI thresholds based on the PSA results. Moreover, many previous PSA results have been changed in Korea since the previous pilot study to reflect the plant-specific data and design changes.

Because there are five reactor types (WH900, WH600, OPR1000, Framatome, and CANDU) used in Korea, an evaluation of the URS thresholds was performed using the recent PSA results from the five reactor types. The White/Yellow and Yellow/Red thresholds for the URS were evaluated using the PSA results. The Green/White threshold was not evaluated in this study because it is generally not defined using the PSA results but by historical performance, for example using the mean plus he standard deviation.

Table 23. MSPI Sensitivity Results Using the Plant-Specific CCF Multiplier (AFW-MDP)

\begin{tabular}{|c|c|c|c|c|c|}
\hline $\begin{array}{c}\text { Demand Failures in } \\
\text { Three Years }\end{array}$ & WH900 & WH600 & OPR1000 & Framatome & CANDU \\
\hline 0 & $-3.08 \mathrm{E}-08(\mathrm{G})$ & $-2.73 \mathrm{E}-09(\mathrm{G})$ & $-1.01 \mathrm{E}-08(\mathrm{G})$ & $-1.43 \mathrm{E}-09(\mathrm{G})$ & $-4.30 \mathrm{E}-10(\mathrm{G})$ \\
\hline 1 & 6.47E-07 (G) & $5.72 \mathrm{E}-08(\mathrm{G})$ & 2.13E-07 (G) & $3.00 \mathrm{E}-08(\mathrm{G})$ & $1.86 \mathrm{E}-08(\mathrm{G})$ \\
\hline 2 & $1.33 \mathrm{E}-06(\mathrm{~W})$ & $1.17 \mathrm{E}-07$ (G) & 4.35E-07 (G) & $6.13 \mathrm{E}-08(\mathrm{G})$ & $3.76 \mathrm{E}-08(\mathrm{G})$ \\
\hline 3 & $2.00 \mathrm{E}-06(\mathrm{~W})$ & 1.77E-07 (G) & $6.58 \mathrm{E}-07(\mathrm{G})$ & $9.27 \mathrm{E}-08(\mathrm{G})$ & $5.65 \mathrm{E}-08(\mathrm{G})$ \\
\hline 4 & $2.68 \mathrm{E}-06(\mathrm{~W})$ & 2.37E-07 (G) & 8.81E-07 (G) & $1.24 \mathrm{E}-07(\mathrm{G})$ & $7.55 \mathrm{E}-08(\mathrm{G})$ \\
\hline 5 & $3.36 \mathrm{E}-06(\mathrm{~W})$ & 2.97E-07 (G) & $1.10 \mathrm{E}-06(\mathrm{~W})$ & $1.55 \mathrm{E}-07(\mathrm{G})$ & $9.45 \mathrm{E}-08(\mathrm{G})$ \\
\hline 6 & 4.04E-06 (W) & 3.57E-07 (G) & $1.33 \mathrm{E}-06(\mathrm{~W})$ & $1.87 \mathrm{E}-07(\mathrm{G})$ & $1.14 \mathrm{E}-07(\mathrm{G})$ \\
\hline 7 & $4.72 \mathrm{E}-06(\mathrm{~W})$ & 4.17E-07 (G) & $1.55 \mathrm{E}-06(\mathrm{~W})$ & $2.18 \mathrm{E}-07(\mathrm{G})$ & $1.33 \mathrm{E}-07(\mathrm{G})$ \\
\hline 8 & 5.39E-06 (W) & 4.77E-07 (G) & 1.77E-06 (W) & $2.50 \mathrm{E}-07(\mathrm{G})$ & $1.51 \mathrm{E}-07(\mathrm{G})$ \\
\hline 9 & $6.07 \mathrm{E}-06(\mathrm{~W})$ & 5.37E-07 (G) & $1.99 \mathrm{E}-06(\mathrm{~W})$ & $2.81 \mathrm{E}-07(\mathrm{G})$ & $1.70 \mathrm{E}-07(\mathrm{G})$ \\
\hline 10 & $6.75 \mathrm{E}-06(\mathrm{~W})$ & 5.97E-07 (G) & $2.22 \mathrm{E}-06(\mathrm{~W})$ & 3.12E-07 (G) & $1.89 \mathrm{E}-07(\mathrm{G})$ \\
\hline 11 & 7.43E-06 (W) & $6.57 \mathrm{E}-07(\mathrm{G})$ & $2.44 \mathrm{E}-06(\mathrm{~W})$ & $3.44 \mathrm{E}-07(\mathrm{G})$ & $2.08 \mathrm{E}-07(\mathrm{G})$ \\
\hline 12 & 8.11E-06 (W) & 7.17E-07 (G) & $2.66 \mathrm{E}-06(\mathrm{~W})$ & $3.75 \mathrm{E}-07(\mathrm{G})$ & $2.27 \mathrm{E}-07(\mathrm{G})$ \\
\hline 13 & $8.78 \mathrm{E}-06(\mathrm{~W})$ & 7.77E-07 (G) & $2.89 \mathrm{E}-06(\mathrm{~W})$ & 4.07E-07 (G) & $2.46 \mathrm{E}-07(\mathrm{G})$ \\
\hline 14 & $9.46 \mathrm{E}-06(\mathrm{~W})$ & $8.37 \mathrm{E}-07(\mathrm{G})$ & $3.11 \mathrm{E}-06(\mathrm{~W})$ & $4.38 \mathrm{E}-07(\mathrm{G})$ & $2.65 \mathrm{E}-07(\mathrm{G})$ \\
\hline 15 & $1.01 \mathrm{E}-05(\mathrm{Y})$ & 8.97E-07 (G) & 3.33E-06 (W) & 4.69E-07 (G) & $2.84 \mathrm{E}-07(\mathrm{G})$ \\
\hline 16 & $1.08 \mathrm{E}-05(\mathrm{Y})$ & 9.57E-07 (G) & $3.55 \mathrm{E}-06(\mathrm{~W})$ & 5.01E-07 (G) & $3.03 \mathrm{E}-07(\mathrm{G})$ \\
\hline 17 & $1.15 \mathrm{E}-05(\mathrm{Y})$ & $1.02 \mathrm{E}-06(\mathrm{~W})$ & $3.78 \mathrm{E}-06(\mathrm{~W})$ & 5.32E-07 (G) & $3.22 \mathrm{E}-07(\mathrm{G})$ \\
\hline 18 & $1.22 \mathrm{E}-05(\mathrm{Y})$ & $1.08 \mathrm{E}-06(\mathrm{~W})$ & 4.00E-06 (W) & 5.63E-07 (G) & $3.41 \mathrm{E}-07(\mathrm{G})$ \\
\hline 19 & $1.29 \mathrm{E}-05(\mathrm{Y})$ & $1.14 \mathrm{E}-06(\mathrm{~W})$ & 4.22E-06 (W) & $5.95 \mathrm{E}-07(\mathrm{G})$ & $3.60 \mathrm{E}-07(\mathrm{G})$ \\
\hline 20 & $1.35 \mathrm{E}-05(\mathrm{Y})$ & $1.20 \mathrm{E}-06(\mathrm{~W})$ & 4.44E-06 (W) & $6.26 \mathrm{E}-07(\mathrm{G})$ & $3.79 \mathrm{E}-07(\mathrm{G})$ \\
\hline
\end{tabular}


To evaluate the URS thresholds using the PSA results, it was assumed that the initiating event frequencies increase by the same percentage as the value of the URS. However, this is unrealistic as a simple scaling of all initiating event frequencies by the same factor would result in a proportionate increase in CDF. Because the initiating events are not all equal in their risk significance, and the purpose of using the PI in graded regulation is to determine when it is appropriate for a regulatory body to initiate a response, it is more meaningful to perform sensitivity studies by only increasing frequencies of the initiating events that are expected to occur. In the USNRC, the frequencies of those rare but potentially risk significant initiating events, such as LOCA, SGTR, and LOOP, and support system failure were not increased when performing the sensitivity studies to determine the thresholds of the URS in SECY 99-007 [15]. Different initiating events can be classified as rare events in Korea, because some initiating event frequencies in Korea are different to those in the USA. For example, LOOP cannot be classified as a rare event in Korea because its frequency occurrence is relatively high, as presented in Table 17. Kang et al. [20] suggested an initiating event frequency of $5.0 \mathrm{E}-3 / \mathrm{yr}$ as a criterion to classify rare initiating events, because Korean NPPs are typically in operation for more than 100 reactor years: this criterion represents events that could occur more than once during a cycle of 100 reactor years. Therefore, sensitivity studies were performed by changing the frequencies of only those initiating events whose ${ }^{18}$ Performance Limit Exceeded (PLE) states that the safety grade is
'White' because failure numbers exceed the backstop values.

Table 24. MSPI Sensitivity Results Using the Plant-Specific CCF Multiplier and Backstop (EAC-EDG)

\begin{tabular}{|c|c|c|c|c|c|}
\hline $\begin{array}{c}\text { Demand Failures in } \\
\text { Three Years }\end{array}$ & WH900 & WH600 & OPR1000 & Framatome & CANDU \\
\hline 0 & $-8.31 \mathrm{E}-08(\mathrm{G})$ & $-1.42 \mathrm{E}-07(\mathrm{G})$ & $-3.09 \mathrm{E}-08(\mathrm{G})$ & $-1.07 \mathrm{E}-06(\mathrm{G})$ & $-3.72 \mathrm{E}-08(\mathrm{G})$ \\
\hline 1 & $1.48 \mathrm{E}-07(\mathrm{G})$ & $2.53 \mathrm{E}-07(\mathrm{G})$ & $5.49 \mathrm{E}-08(\mathrm{G})$ & $1.90 \mathrm{E}-06(\mathrm{~W})$ & 6.61E-08 (G) \\
\hline 2 & $3.78 \mathrm{E}-07(\mathrm{~W})$ & $6.49 \mathrm{E}-07(\mathrm{G})$ & $1.41 \mathrm{E}-07(\mathrm{G})$ & $4.88 \mathrm{E}-06(\mathrm{~W})$ & $1.69 \mathrm{E}-07(\mathrm{G})$ \\
\hline 3 & $6.09 \mathrm{E}-07(\mathrm{~W})$ & $1.04 \mathrm{E}-06(\mathrm{~W})$ & $2.26 \mathrm{E}-07(\mathrm{G})$ & $7.85 \mathrm{E}-06(\mathrm{~W})$ & $2.73 \mathrm{E}-07(\mathrm{G})$ \\
\hline 4 & $8.40 \mathrm{E}-07(\mathrm{~W})$ & $1.44 \mathrm{E}-06(\mathrm{~W})$ & $3.12 \mathrm{E}-07(\mathrm{G})$ & $1.08 \mathrm{E}-05(\mathrm{Y})$ & $3.76 \mathrm{E}-07(\mathrm{G})$ \\
\hline 5 & $1.07 \mathrm{E}-06(\mathrm{~W})$ & $1.84 \mathrm{E}-06(\mathrm{~W})$ & $3.98 \mathrm{E}-07(\mathrm{G})$ & $1.38 \mathrm{E}-05(\mathrm{Y})$ & 4.79E-07 (G) \\
\hline 6 & $1.30 \mathrm{E}-06(\mathrm{~W})$ & $2.23 \mathrm{E}-06(\mathrm{~W})$ & $4.83 \mathrm{E}-07(\mathrm{G})$ & $1.68 \mathrm{E}-05(\mathrm{Y})$ & $5.82 \mathrm{E}-07(\mathrm{G})$ \\
\hline 7 & $1.53 \mathrm{E}-06(\mathrm{~W})$ & $2.63 \mathrm{E}-06(\mathrm{~W})$ & $5.69 \mathrm{E}-07(\mathrm{G})$ & $1.98 \mathrm{E}-05(\mathrm{Y})$ & $6.86 \mathrm{E}-07(\mathrm{G})$ \\
\hline 8 & $1.76 \mathrm{E}-06(\mathrm{Y})$ & $3.02 \mathrm{E}-06(\mathrm{~W})$ & $\operatorname{PLE}^{18}(\mathrm{~W})$ & $2.27 \mathrm{E}-05(\mathrm{Y})$ & PLE (W) \\
\hline 9 & $1.99 \mathrm{E}-06(\mathrm{Y})$ & $3.42 \mathrm{E}-06(\mathrm{~W})$ & PLE (W) & $2.57 \mathrm{E}-05(\mathrm{Y})$ & PLE (W) \\
\hline 10 & $2.22 \mathrm{E}-06(\mathrm{Y})$ & $3.82 \mathrm{E}-06(\mathrm{~W})$ & PLE (W) & $2.87 \mathrm{E}-05(\mathrm{Y})$ & PLE (W) \\
\hline 11 & $2.46 \mathrm{E}-06(\mathrm{Y})$ & $4.21 \mathrm{E}-06(\mathrm{~W})$ & $\operatorname{PLE}(\mathrm{W})$ & $3.17 \mathrm{E}-05(\mathrm{Y})$ & $1.10 \mathrm{E}-06(\mathrm{~W})$ \\
\hline 12 & $2.69 \mathrm{E}-06(\mathrm{Y})$ & $4.61 \mathrm{E}-06(\mathrm{~W})$ & PLE (W) & $3.46 \mathrm{E}-05(\mathrm{Y})$ & $1.20 \mathrm{E}-06(\mathrm{~W})$ \\
\hline 13 & $2.92 \mathrm{E}-06(\mathrm{Y})$ & $5.00 \mathrm{E}-06(\mathrm{~W})$ & $1.08 \mathrm{E}-06(\mathrm{~W})$ & $3.76 \mathrm{E}-05(\mathrm{Y})$ & $1.30 \mathrm{E}-06(\mathrm{~W})$ \\
\hline 14 & $3.15 \mathrm{E}-06(\mathrm{Y})$ & $5.40 \mathrm{E}-06(\mathrm{~W})$ & $1.17 \mathrm{E}-06(\mathrm{~W})$ & $4.06 \mathrm{E}-05(\mathrm{Y})$ & $1.41 \mathrm{E}-06(\mathrm{~W})$ \\
\hline 15 & $3.38 \mathrm{E}-06(\mathrm{Y})$ & $5.79 \mathrm{E}-06(\mathrm{~W})$ & $1.25 \mathrm{E}-06(\mathrm{~W})$ & $4.35 \mathrm{E}-05(\mathrm{Y})$ & $1.51 \mathrm{E}-06(\mathrm{~W})$ \\
\hline 16 & $3.61 \mathrm{E}-06(\mathrm{Y})$ & $6.19 \mathrm{E}-06(\mathrm{~W})$ & $1.34 \mathrm{E}-06(\mathrm{~W})$ & $4.65 \mathrm{E}-05(\mathrm{Y})$ & $1.61 \mathrm{E}-06(\mathrm{~W})$ \\
\hline 17 & $3.84 \mathrm{E}-06(\mathrm{Y})$ & $6.59 \mathrm{E}-06(\mathrm{~W})$ & $1.43 \mathrm{E}-06(\mathrm{~W})$ & 4.95E-05 (Y) & $1.72 \mathrm{E}-06(\mathrm{~W})$ \\
\hline 18 & $4.07 \mathrm{E}-06(\mathrm{Y})$ & $6.98 \mathrm{E}-06(\mathrm{~W})$ & $1.51 \mathrm{E}-06(\mathrm{~W})$ & $5.25 \mathrm{E}-05(\mathrm{Y})$ & $1.82 \mathrm{E}-06(\mathrm{~W})$ \\
\hline 19 & $4.30 \mathrm{E}-06(\mathrm{Y})$ & $7.38 \mathrm{E}-06(\mathrm{~W})$ & $1.60 \mathrm{E}-06(\mathrm{~W})$ & $5.54 \mathrm{E}-05(\mathrm{Y})$ & $1.92 \mathrm{E}-06(\mathrm{~W})$ \\
\hline 20 & $4.53 \mathrm{E}-06(\mathrm{Y})$ & 7.77E-06 (W) & $1.68 \mathrm{E}-06(\mathrm{~W})$ & 5.84E-05(Y) & $2.03 \mathrm{E}-06(\mathrm{~W})$ \\
\hline
\end{tabular}


frequencies were above 5.0E-3/yr. Moreover, because the URS is based on critical reactor years and the initiating event frequencies are based on calendar years, the applicable URS thresholds were adjusted by incorporating the plant availability factor. For example, if the summation of the changes in the initiating event frequency 6.0/yr results in $1.0 \mathrm{E}-5 / \mathrm{yr}$ delta $\mathrm{CDF}$ and the plant availability factor is assumed as $80 \%$, the applicable URS is defined as $4.8 / \mathrm{yr}(=6.0 / \mathrm{yr} * 80 \%)$.

The evaluation results of the URS thresholds using the recent PSA results from the different reactor types are presented in Table 30. The evaluation results of the present study Kang et al. [20] and the threshold used in the existing KINS SPI are also presented for comparison. From Table 30 it can be seen that the URS thresholds estimated in this study are significantly different between the reactor types. The results from the CDF contributions of each initiating event and the baseline CDF values are different for each reactor type. The URS thresholds estimated in this study are also different from those estimated by Kang et al. [20] because more recent PSA results were used in this study.

The URS thresholds estimated from this study, which are based on PSA results, are generally higher than the corresponding KINS SPI thresholds. This means that the existing URS thresholds of KINS SPI are conservative for most Korean NPPs. Therefore, the existing URS thresholds of KINS SPI can be considered acceptable for use in Korean NPPs. The thresholds estimated using the WH600 PSA results were lower than the KINS SPI thresholds, however, due to the higher baseline CDF values of the WH600 compared with the other reactor types [19]. Nonetheless, the modification of the URS thresholds based on the WH600 PSA result cannot be

Table 25. MSPI Sensitivity Results Using the Plant-Specific CCF Multiplier and Backstop (HPSI-MDP)

\begin{tabular}{|c|c|c|c|c|c|}
\hline $\begin{array}{l}\text { Demand Failures in } \\
\text { Three Years }\end{array}$ & WH900 & WH600 & OPR1000 & Framatome & CANDU \\
\hline 0 & $-2.61 \mathrm{E}-09(\mathrm{G})$ & $-2.89 \mathrm{E}-09(\mathrm{G})$ & $-2.65 \mathrm{E}-08(\mathrm{G})$ & $-8.66 \mathrm{E}-12(\mathrm{G})$ & $-3.79 \mathrm{E}-10(\mathrm{G})$ \\
\hline 1 & $6.90 \mathrm{E}-08(\mathrm{G})$ & $6.08 \mathrm{E}-08(\mathrm{G})$ & $5.56 \mathrm{E}-07(\mathrm{G})$ & $3.45 \mathrm{E}-10(\mathrm{G})$ & $7.96 \mathrm{E}-09(\mathrm{G})$ \\
\hline 2 & $1.41 \mathrm{E}-07(\mathrm{G})$ & $1.24 \mathrm{E}-07(\mathrm{G})$ & $1.14 \mathrm{E}-06(\mathrm{~W})$ & $6.98 \mathrm{E}-10(\mathrm{G})$ & $1.63 \mathrm{E}-08(\mathrm{G})$ \\
\hline 3 & $2.12 \mathrm{E}-07(\mathrm{G})$ & $1.88 \mathrm{E}-07(\mathrm{G})$ & $1.72 \mathrm{E}-06(\mathrm{~W})$ & $1.05 \mathrm{E}-09(\mathrm{G})$ & $2.47 \mathrm{E}-08(\mathrm{G})$ \\
\hline 4 & $2.84 \mathrm{E}-07(\mathrm{G})$ & $2.52 \mathrm{E}-07(\mathrm{G})$ & $2.30 \mathrm{E}-06(\mathrm{~W})$ & $1.41 \mathrm{E}-09(\mathrm{G})$ & $3.30 \mathrm{E}-08(\mathrm{G})$ \\
\hline 5 & $3.55 \mathrm{E}-07(\mathrm{G})$ & $3.15 \mathrm{E}-07(\mathrm{G})$ & $2.89 \mathrm{E}-06(\mathrm{~W})$ & $1.76 \mathrm{E}-09(\mathrm{G})$ & 4.13E-08 (G) \\
\hline 6 & 4.27E-07 (G) & PLE (W) & $3.47 \mathrm{E}-06(\mathrm{~W})$ & $2.11 \mathrm{E}-09(\mathrm{G})$ & PLE (W) \\
\hline 7 & $4.98 \mathrm{E}-07(\mathrm{~W})$ & $\operatorname{PLE}(\mathrm{W})$ & $4.05 \mathrm{E}-06(\mathrm{~W})$ & PLE (W) & PLE (W) \\
\hline 8 & $5.70 \mathrm{E}-07(\mathrm{~W})$ & PLE (W) & $4.63 \mathrm{E}-06(\mathrm{~W})$ & PLE (W) & PLE (W) \\
\hline 9 & $6.42 \mathrm{E}-07(\mathrm{~W})$ & PLE (W) & $5.22 \mathrm{E}-06(\mathrm{~W})$ & PLE (W) & PLE (W) \\
\hline 10 & $7.13 \mathrm{E}-07(\mathrm{~W})$ & PLE (W) & $5.80 \mathrm{E}-06(\mathrm{~W})$ & PLE (W) & $\operatorname{PLE}(\mathrm{W})$ \\
\hline 11 & $7.85 \mathrm{E}-07(\mathrm{~W})$ & PLE (W) & $6.38 \mathrm{E}-06(\mathrm{~W})$ & PLE (W) & $\operatorname{PLE}(\mathrm{W})$ \\
\hline 12 & $8.56 \mathrm{E}-07(\mathrm{~W})$ & PLE (W) & $6.96 \mathrm{E}-06(\mathrm{~W})$ & PLE (W) & PLE (W) \\
\hline 13 & $9.28 \mathrm{E}-07(\mathrm{~W})$ & PLE (W) & $7.55 \mathrm{E}-06(\mathrm{~W})$ & PLE (W) & $\operatorname{PLE}(\mathrm{W})$ \\
\hline 14 & $1.00 \mathrm{E}-06(\mathrm{~W})$ & PLE (W) & $8.13 \mathrm{E}-06(\mathrm{~W})$ & PLE (W) & PLE (W) \\
\hline 15 & $1.07 \mathrm{E}-06(\mathrm{~W})$ & PLE (W) & $8.71 \mathrm{E}-06(\mathrm{~W})$ & PLE (W) & $\operatorname{PLE}(\mathrm{W})$ \\
\hline 16 & $1.14 \mathrm{E}-06(\mathrm{~W})$ & $1.02 \mathrm{E}-06(\mathrm{~W})$ & $9.30 \mathrm{E}-06(\mathrm{~W})$ & PLE (W) & $\operatorname{PLE}(\mathrm{W})$ \\
\hline 17 & $1.21 \mathrm{E}-06(\mathrm{~W})$ & $1.08 \mathrm{E}-06(\mathrm{~W})$ & $9.88 \mathrm{E}-06(\mathrm{~W})$ & PLE (W) & PLE (W) \\
\hline 18 & $1.29 \mathrm{E}-06(\mathrm{~W})$ & $1.14 \mathrm{E}-06(\mathrm{~W})$ & $1.05 \mathrm{E}-05(\mathrm{Y})$ & PLE (W) & $\operatorname{PLE}(\mathrm{W})$ \\
\hline 19 & $1.36 \mathrm{E}-06(\mathrm{~W})$ & $1.21 \mathrm{E}-06(\mathrm{~W})$ & $1.10 \mathrm{E}-05(\mathrm{Y})$ & $\operatorname{PLE}(\mathrm{W})$ & $\operatorname{PLE}(\mathrm{W})$ \\
\hline 20 & $1.43 \mathrm{E}-06(\mathrm{~W})$ & $1.27 \mathrm{E}-06(\mathrm{~W})$ & $1.16 \mathrm{E}-05(\mathrm{Y})$ & $\operatorname{PLE}(\mathrm{W})$ & $\operatorname{PLE}(\mathrm{W})$ \\
\hline
\end{tabular}


regarded as a feasible approach because it will create a very sensitive PI result; for example, two reactor scrams per year can yield 'Yellow' if the URS thresholds based on the WH600 PSA result presented in Table 30 are used, which will instead cause adverse effects on safety. Thus, it is suggested that the existing URS thresholds of the KINS SPI system remain the same for the graded regulation program.

\subsection{Evaluation of Other PI Thresholds in KINS SPI (Reactor Safety Area)}

The KINS SPIs in safety areas other than the URS and SSU are as follows:

[Operational Safety Category]

- Unplanned Power Reduction (UPR)

[Multiple Barrier Category]
- Fuel Reliability (FR)

- Reactor Coolant Leakage (RCL)

- Containment Integrity (CI)

- Emergency Preparedness (EP)

Detailed definitions of KINS SPIs are documented in reference [3]. As presented in Table 1, the thresholds of these SPIs are established for all safety grades (Green, Cyan, Yellow, Orange) in the existing KINS SPI system. This can be regarded as an appropriate method for the current usage of the KINS SPI system, monitoring the plant safety performance for trending, enhancing public confidence, and so on.

However, it is not appropriate to directly use the thresholds of the existing KINS SPI system for graded regulation. Specifically, too many Orange indicators can occur in the existing KINS SPI system regardless of their risk significance, thus making the KINS SPI meaningless

Table 26. MSPI Sensitivity Results Using the Plant-Specific CCF Multiplier and Backstop (RHR-MDP)

\begin{tabular}{|c|c|c|c|c|c|}
\hline $\begin{array}{l}\text { Demand Failures in } \\
\text { Three Years }\end{array}$ & WH900 & WH600 & OPR1000 & Framatome & CANDU \\
\hline 0 & $-1.08 \mathrm{E}-08(\mathrm{G})$ & $1.81 \mathrm{E}-08(\mathrm{G})$ & $3.19 \mathrm{E}-08(\mathrm{G})$ & $1.13 \mathrm{E}-09(\mathrm{G})$ & $1.04 \mathrm{E}-08(\mathrm{G})$ \\
\hline 1 & $2.27 \mathrm{E}-07(\mathrm{G})$ & $1.52 \mathrm{E}-07(\mathrm{G})$ & $2.02 \mathrm{E}-07(\mathrm{G})$ & $6.48 \mathrm{E}-09(\mathrm{G})$ & $5.96 \mathrm{E}-08(\mathrm{G})$ \\
\hline 2 & 4.64E-07 (G) & $2.87 \mathrm{E}-07(\mathrm{G})$ & $3.72 \mathrm{E}-07(\mathrm{G})$ & $1.18 \mathrm{E}-08(\mathrm{G})$ & $1.09 \mathrm{E}-07(\mathrm{G})$ \\
\hline 3 & $7.01 \mathrm{E}-07(\mathrm{G})$ & 4.21E-07 (G) & $5.43 \mathrm{E}-07(\mathrm{G})$ & $1.72 \mathrm{E}-08(\mathrm{G})$ & $1.58 \mathrm{E}-07(\mathrm{G})$ \\
\hline 4 & 9.39E-07 (G) & $5.55 \mathrm{E}-07(\mathrm{G})$ & $7.13 \mathrm{E}-07(\mathrm{G})$ & $2.25 \mathrm{E}-08(\mathrm{G})$ & $2.07 \mathrm{E}-07(\mathrm{G})$ \\
\hline 5 & $1.18 \mathrm{E}-06(\mathrm{~W})$ & $6.90 \mathrm{E}-07(\mathrm{G})$ & 8.83E-07 (G) & $2.79 \mathrm{E}-08(\mathrm{G})$ & $2.56 \mathrm{E}-07(\mathrm{G})$ \\
\hline 6 & $1.41 \mathrm{E}-06(\mathrm{~W})$ & PLE (W) & $1.05 \mathrm{E}-06(\mathrm{~W})$ & $\operatorname{PLE}(\mathrm{W})$ & PLE (W) \\
\hline 7 & $1.65 \mathrm{E}-06(\mathrm{~W})$ & PLE (W) & $1.22 \mathrm{E}-06(\mathrm{~W})$ & $\operatorname{PLE}(\mathrm{W})$ & PLE (W) \\
\hline 8 & $1.89 \mathrm{E}-06(\mathrm{~W})$ & $1.09 \mathrm{E}-06(\mathrm{~W})$ & $1.39 \mathrm{E}-06(\mathrm{~W})$ & PLE (W) & PLE (W) \\
\hline 9 & $2.13 \mathrm{E}-06(\mathrm{~W})$ & $1.23 \mathrm{E}-06(\mathrm{~W})$ & $1.56 \mathrm{E}-06(\mathrm{~W})$ & PLE (W) & PLE (W) \\
\hline 10 & $2.36 \mathrm{E}-06(\mathrm{~W})$ & $1.36 \mathrm{E}-06(\mathrm{~W})$ & $1.73 \mathrm{E}-06(\mathrm{~W})$ & $\operatorname{PLE}(\mathrm{W})$ & PLE (W) \\
\hline 11 & $2.60 \mathrm{E}-06(\mathrm{~W})$ & $1.50 \mathrm{E}-06(\mathrm{~W})$ & $1.90 \mathrm{E}-06(\mathrm{~W})$ & $\operatorname{PLE}(\mathrm{W})$ & PLE (W) \\
\hline 12 & $2.84 \mathrm{E}-06(\mathrm{~W})$ & $1.63 \mathrm{E}-06(\mathrm{~W})$ & $2.07 \mathrm{E}-06(\mathrm{~W})$ & PLE (W) & PLE (W) \\
\hline 13 & $3.07 \mathrm{E}-06(\mathrm{~W})$ & $1.76 \mathrm{E}-06(\mathrm{~W})$ & $2.24 \mathrm{E}-06(\mathrm{~W})$ & $\operatorname{PLE}(\mathrm{W})$ & PLE (W) \\
\hline 14 & $3.31 \mathrm{E}-06(\mathrm{~W})$ & $1.90 \mathrm{E}-06(\mathrm{~W})$ & $2.42 \mathrm{E}-06(\mathrm{~W})$ & $\operatorname{PLE}(\mathrm{W})$ & $\operatorname{PLE}(\mathrm{W})$ \\
\hline 15 & $3.55 \mathrm{E}-06(\mathrm{~W})$ & $2.03 \mathrm{E}-06(\mathrm{~W})$ & $2.59 \mathrm{E}-06(\mathrm{~W})$ & PLE (W) & PLE (W) \\
\hline 16 & $3.79 \mathrm{E}-06(\mathrm{~W})$ & $2.17 \mathrm{E}-06(\mathrm{~W})$ & $2.76 \mathrm{E}-06(\mathrm{~W})$ & $\operatorname{PLE}(\mathrm{W})$ & PLE (W) \\
\hline 17 & $4.02 \mathrm{E}-06(\mathrm{~W})$ & $2.30 \mathrm{E}-06(\mathrm{~W})$ & $2.93 \mathrm{E}-06(\mathrm{~W})$ & $\operatorname{PLE}(\mathrm{W})$ & PLE (W) \\
\hline 18 & $4.26 \mathrm{E}-06(\mathrm{~W})$ & $2.44 \mathrm{E}-06(\mathrm{~W})$ & $3.10 \mathrm{E}-06(\mathrm{~W})$ & $\operatorname{PLE}(\mathrm{W})$ & PLE (W) \\
\hline 19 & $4.50 \mathrm{E}-06(\mathrm{~W})$ & $2.57 \mathrm{E}-06(\mathrm{~W})$ & $3.27 \mathrm{E}-06(\mathrm{~W})$ & PLE (W) & PLE (W) \\
\hline 20 & 4.74E-06 (W) & $2.70 \mathrm{E}-06(\mathrm{~W})$ & $3.44 \mathrm{E}-06(\mathrm{~W})$ & $\operatorname{PLE}(\mathrm{W})$ & PLE (W) \\
\hline
\end{tabular}


in the graded regulation program. Therefore, in this study, it was considered inappropriate that all SPIs have thresholds for all safety grades.

First, for the UPR in the operational safety category, the Green/Cyan (Green/White) threshold is determined by considering the historical performance. For example,
SECY99-007 [15] indicates that the threshold in the USNRC was determined based on the industry mean plus the standard deviation based on data from July 1, 1995 through June 30, 1997. A recent report in KINS [3] also indicates that the threshold has been defined considering the historical performance of domestic NPPs. This is

Table 27. MSPI Sensitivity Results Using the Plant-Specific CCF Multiplier and Backstop (AFW-MDP)

\begin{tabular}{|c|c|c|c|c|c|}
\hline $\begin{array}{c}\text { Demand Failures in } \\
\text { Three Years }\end{array}$ & WH900 & WH600 & OPR1000 & Framatome & CANDU \\
\hline 0 & $-3.08 \mathrm{E}-08(\mathrm{G})$ & $-2.73 \mathrm{E}-09(\mathrm{G})$ & $-1.01 \mathrm{E}-08(\mathrm{G})$ & $-1.43 \mathrm{E}-09(\mathrm{G})$ & $-4.30 \mathrm{E}-10(\mathrm{G})$ \\
\hline 1 & 6.47E-07 (G) & $5.72 \mathrm{E}-08(\mathrm{G})$ & $2.13 \mathrm{E}-07(\mathrm{G})$ & $3.00 \mathrm{E}-08(\mathrm{G})$ & $1.86 \mathrm{E}-08(\mathrm{G})$ \\
\hline 2 & $1.33 \mathrm{E}-06(\mathrm{~W})$ & 1.17E-07 (G) & 4.35E-07 (G) & $6.13 \mathrm{E}-08(\mathrm{G})$ & $3.76 \mathrm{E}-08(\mathrm{G})$ \\
\hline 3 & $2.00 \mathrm{E}-06(\mathrm{~W})$ & 1.77E-07 (G) & $6.58 \mathrm{E}-07(\mathrm{G})$ & $9.27 \mathrm{E}-08(\mathrm{G})$ & $5.65 \mathrm{E}-08(\mathrm{G})$ \\
\hline 4 & $2.68 \mathrm{E}-06(\mathrm{~W})$ & 2.37E-07 (G) & 8.81E-07 (G) & $1.24 \mathrm{E}-07(\mathrm{G})$ & $7.55 \mathrm{E}-08(\mathrm{G})$ \\
\hline 5 & $3.36 \mathrm{E}-06(\mathrm{~W})$ & 2.97E-07 (G) & $1.10 \mathrm{E}-06(\mathrm{~W})$ & $1.55 \mathrm{E}-07(\mathrm{G})$ & $9.45 \mathrm{E}-08(\mathrm{G})$ \\
\hline 6 & $4.04 \mathrm{E}-06(\mathrm{~W})$ & PLE (W) & $1.33 \mathrm{E}-06(\mathrm{~W})$ & PLE (W) & PLE (W) \\
\hline 7 & 4.72E-06 (W) & $\operatorname{PLE}(\mathrm{W})$ & $1.55 \mathrm{E}-06(\mathrm{~W})$ & $\operatorname{PLE}(\mathrm{W})$ & PLE (W) \\
\hline 8 & 5.39E-06 (W) & $\operatorname{PLE}(\mathrm{W})$ & 1.77E-06 (W) & $\operatorname{PLE}(\mathrm{W})$ & PLE (W) \\
\hline 9 & $6.07 \mathrm{E}-06(\mathrm{~W})$ & PLE (W) & $1.99 \mathrm{E}-06(\mathrm{~W})$ & PLE (W) & PLE (W) \\
\hline 10 & $6.75 \mathrm{E}-06(\mathrm{~W})$ & $\operatorname{PLE}(\mathrm{W})$ & $2.22 \mathrm{E}-06(\mathrm{~W})$ & $\operatorname{PLE}(\mathrm{W})$ & $\operatorname{PLE}(\mathrm{W})$ \\
\hline 11 & 7.43E-06 (W) & PLE (W) & 2.44E-06 (W) & PLE (W) & PLE (W) \\
\hline 12 & $8.11 \mathrm{E}-06(\mathrm{~W})$ & $\operatorname{PLE}(\mathrm{W})$ & 2.66E-06 (W) & $\operatorname{PLE}(\mathrm{W})$ & $\operatorname{PLE}(\mathrm{W})$ \\
\hline 13 & $8.78 \mathrm{E}-06(\mathrm{~W})$ & $\operatorname{PLE}(\mathrm{W})$ & $2.89 \mathrm{E}-06(\mathrm{~W})$ & $\operatorname{PLE}(\mathrm{W})$ & $\operatorname{PLE}(\mathrm{W})$ \\
\hline 14 & $9.46 \mathrm{E}-06(\mathrm{~W})$ & $\operatorname{PLE}(\mathrm{W})$ & $3.11 \mathrm{E}-06(\mathrm{~W})$ & $\operatorname{PLE}(\mathrm{W})$ & $\operatorname{PLE}(\mathrm{W})$ \\
\hline 15 & $1.01 \mathrm{E}-05(\mathrm{Y})$ & $\operatorname{PLE}(\mathrm{W})$ & 3.33E-06 (W) & $\operatorname{PLE}(\mathrm{W})$ & PLE (W) \\
\hline 16 & $1.08 \mathrm{E}-05(\mathrm{Y})$ & $\operatorname{PLE}(\mathrm{W})$ & $3.55 \mathrm{E}-06(\mathrm{~W})$ & PLE (W) & $\operatorname{PLE}(\mathrm{W})$ \\
\hline 17 & $1.15 \mathrm{E}-05(\mathrm{Y})$ & $1.02 \mathrm{E}-06(\mathrm{~W})$ & $3.78 \mathrm{E}-06(\mathrm{~W})$ & PLE (W) & $\operatorname{PLE}(\mathrm{W})$ \\
\hline 18 & $1.22 \mathrm{E}-05(\mathrm{Y})$ & $1.08 \mathrm{E}-06(\mathrm{~W})$ & $4.00 \mathrm{E}-06(\mathrm{~W})$ & $\operatorname{PLE}(\mathrm{W})$ & PLE (W) \\
\hline 19 & $1.29 \mathrm{E}-05(\mathrm{Y})$ & $1.14 \mathrm{E}-06(\mathrm{~W})$ & $4.22 \mathrm{E}-06(\mathrm{~W})$ & $\operatorname{PLE}(\mathrm{W})$ & PLE (W) \\
\hline 20 & $1.35 \mathrm{E}-05(\mathrm{Y})$ & $1.20 \mathrm{E}-06(\mathrm{~W})$ & 4.44E-06 (W) & PLE (W) & $\operatorname{PLE}(\mathrm{W})$ \\
\hline
\end{tabular}

Table 28. Implication of Performance Band Used in NRC PI System

\begin{tabular}{c|c}
\hline Performance Band & Implication \\
\hline Green & Acceptable (objective full met) \\
\hline White & Acceptable (minimal reduction in safety margin) \\
\hline Yellow & Acceptable (significant reduction in safety margin) \\
\hline Red & Unacceptable \\
\hline
\end{tabular}


consistent with the principle presented in Figure 1, which is the conceptual framework for establishing performance thresholds for graded regulation. However, the thresholds of Cyan/Yellow (White/Yellow) and Yellow/Orange (Yellow/Red) for the UPR in the existing KINS SPI system should be removed from use in the graded regulation program because it cannot be directly tied to risk data, therefore there is no basis of Cyan/Yellow

Table 29. Implication of Performance Band Used in NRC PI System

\begin{tabular}{c|c}
\hline Performance Band & Implication \\
\hline Green & Excellent \\
\hline Cyan & Good \\
\hline Yellow & Normal \\
\hline Orange & Warning \\
\hline
\end{tabular}

(White/Yellow) and Yellow/Orange (Yellow/Red) thresholds. Thus, it is suggested that the existing UPR thresholds presented in Table 31 should be changed to the thresholds presented in Table 32 .

Secondly, the thresholds of the FR, RCL, and CI in the multiple barrier category are determined based on the TS limits. For example, the FR indicator is defined as 'the percentage of the maximum value of I-131 in the reactor coolant system (RCS) to the limit value of TS [3]'. The most limiting case for these indicators is the TS limit excess. Because the individual plant TS requires a plant shutdown within a short time after the TS limits are exceeded, the TS limit excess can be defined as Yellow (not Red) in establishing performance thresholds as presented in Figure 1. The thresholds used for Yellow/Orange in the existing KINS SPI system should

\footnotetext{
${ }^{19}$ Plant availability factor assumed to be $80 \%$.
}

Table 30. Results of URS PI Thresholds by Using the Representative PSA Results of Korean NPPs

\begin{tabular}{|c|c|c|c|c|}
\hline & & \multirow{2}{*}{$\begin{array}{l}\text { URS Estimated from } \\
\text { Initiating Event } \\
\text { Frequency }^{19}\end{array}$} & \multicolumn{2}{|c|}{ URS PI Thresholds } \\
\hline & & & $\begin{array}{l}\text { White/Yellow } \\
\text { (Cyan/Yellow) } \\
(\Delta \text { CDF 1E-5/yr) }\end{array}$ & $\begin{array}{c}\text { Yellow/Red } \\
\text { (Yellow/Orange) } \\
(\Delta \mathrm{CDF} 1 \mathrm{E}-4 / \mathrm{yr})\end{array}$ \\
\hline \multirow{5}{*}{$\begin{array}{c}\text { Reactor Types Evaluated } \\
\text { in This Study }\end{array}$} & OPR1000 & 1.58 & 11.49 & 100.45 \\
\hline & WH900 & 0.98 & 7.37 & 64.78 \\
\hline & WH600 & 0.89 & 2.69 & 18.87 \\
\hline & Framatome & 1.28 & 6.21 & 50.55 \\
\hline & CANDU & 1.68 & 11.50 & 99.83 \\
\hline \multicolumn{2}{|c|}{ K1 / K2 (Kang et al. [20]) } & $0.991 / 1.208$ & $9.28 / 4.84$ & $84 / 37.5$ \\
\hline \multicolumn{2}{|c|}{ KINS SPI [3] } & - & 6 & 20 \\
\hline
\end{tabular}

Table 31. UPR Thresholds Used in KINS

\begin{tabular}{c|c|c|c|c}
\hline Performance Indicator & Green & Cyan & Yellow & Orange \\
\hline Unplanned Power Reduction & $<1.5(6 / \mathrm{yr})$ & $\geq 1.5(6 / \mathrm{yr})$ & $\geq 3(12 / \mathrm{yr})$ & $\geq 5(20 / \mathrm{yr})$ \\
\hline
\end{tabular}

Table 32. UPR Thresholds Proposed in This Study

\begin{tabular}{c|c|c|c|c}
\hline Performance Indicator & Green & White & Yellow & Red \\
\hline Unplanned Power Reduction & $<1.5(6 / \mathrm{yr})$ & $\geq 1.5(6 / \mathrm{yr})$ & No Threshold & No Threshold \\
\hline
\end{tabular}


be used for the White/Yellow (not Yellow/Red) thresholds in the graded regulation program. Similarly, the thresholds of the EP in the multiple barrier category should also change. The thresholds of the EP are determined based on engineering judgment and do not have a direct relationship with the risk data. Therefore, allocation of the Red threshold for EP is not considered feasible for use in the graded regulation program. It is suggested that the existing thresholds of the FR, RCL, $\mathrm{CI}$, and EP in the multiple barrier category presented in Table 33 should be changed to those presented in Table 34.

\section{CONCLUSIONS AND RECOMMENDATIONS}

First, the recently developed PIs of the USNRC that use risk information have been investigated and a feasibility study for the application of these PIs to Korean NPPs has been undertaken. The PIs investigated are the BRIIE, USwC, and MSPI. The following are noted from the feasibility study for these PIs.

[BRIIE]

- The BRIIE cannot be used directly in the graded regulation for individual NPPs because it is an industry level PI. Therefore, it is not necessary to include the BRIIE in the KINS SPI program.

- However, it may be necessary to adopt the BRIIE as an industry level initiating event PI in Korea because the risk-significant initiating events can be effectively monitored using the BRIIE. The URS PI alone cannot sufficiently cover the risk of Korean NPPs.

- Specific prediction limits for Korea as presented in Table 4, which differs from those of the US NPP industry, need to be determined if the BRIIE is selected as an initiating event PI for Korean NPPs.

[USwC]

- The USwC can be used as a meaningful PI to monitor potentially risk-significant initiating events at the plant level. It can directly used in graded regulations for individual NPPs.

- If the USwC is used as an initiating event PI for Korean NPPs, it could use a similar threshold as that of the USwC used in the USNRC ROP.

[MSPI]

- The MSPI has many advantages compared with the SSU that is presently used in KINS because MSPI can consider plant-specific risk characteristics, accurate unreliability including CCF using plantspecific PSA results, and so on.

- The CCF multipliers are an important contributor in the MSPI results. It was generally more conservative to use the plant-specific CCF multipliers than the generic CCF multipliers in this sensitivity study.

- The MSPI results of some systems remained 'Green' even if a large number of failures occurred due to the relatively small Birnbaums. The basis of the small Birnbaums for some components must be checked before implementation of the MSPI because small Birnbaums can result not from design differences but from different initiating event data, PSA modeling

Table 33. RF, RCL, Cl, and EP Thresholds Used in KINS

\begin{tabular}{c|c|c|c|c}
\hline Performance Indicator & Green & Cyan & Yellow & Orange \\
\hline Fuel Reliability & $<50 \%$ TS limit & $\geq 50 \%$ TS limit & $\geq 70 \%$ TS limit & $\geq 100 \%$ TS limit \\
\hline Reactor Coolant Leakage & $<50 \%$ TS limit & $\geq 50 \%$ TS limit & $\geq 70 \%$ TS limit & $\geq 100 \%$ TS limit \\
\hline Containment Reliability & $\geq 90 \%$ & $<90 \%$ & $<80 \%$ & $<60 \%$ \\
\hline Emergency Preparedness & $\geq 90 \%$ & $<90 \%$ & $<80 \%$ & $<60 \%$ \\
\hline
\end{tabular}

Table 34. RF, RCL, Cl, EP Thresholds Proposed in This Study

\begin{tabular}{c|c|c|c|c}
\hline Performance Indicator & Green & White & Yellow & Red \\
\hline Fuel Reliability & $<50 \%$ TS limit & $\geq 50 \%$ TS limit & $\geq 100 \%$ TS limit & No Threshold \\
\hline Reactor Coolant Leakage & $<50 \%$ TS limit & $\geq 50 \%$ TS limit & $\geq 100 \%$ TS limit & No Threshold \\
\hline Containment Reliability & $\geq 90 \%$ & $<90 \%$ & No Threshold \\
\hline Emergency Preparedness & $\geq 90 \%$ & $<90 \%$ & $<60 \%$ & No Threshold \\
\hline
\end{tabular}


Table 35. Performance Indicators and Thresholds Proposed in This Study for Graded Regulation

\begin{tabular}{|c|c|c|c|c|c|c|}
\hline \multirow{2}{*}{ Area } & \multirow{2}{*}{ Category } & \multirow{2}{*}{$\begin{array}{l}\text { Specific Performance } \\
\text { Indicator }\end{array}$} & \multicolumn{4}{|c|}{ Grade \& Color Coding (yearly) } \\
\hline & & & Green & White & Yellow & Red \\
\hline \multirow{12}{*}{$\begin{array}{l}\text { Reactor } \\
\text { Safety }\end{array}$} & \multirow{3}{*}{$\begin{array}{l}\text { Operational } \\
\text { Safety }\end{array}$} & Unplanned Reactor Scram & $<3$ & $\geq 3$ & $\geq 6$ & $\geq 20$ \\
\hline & & Unplanned Power Reduction & $<6$ & $\geq 6$ & No Threshold & No Threshold \\
\hline & & USwC & $<2$ & $\geq 2$ & No Threshold & No Threshold \\
\hline & \multirow{4}{*}{$\begin{array}{l}\text { Multiple } \\
\text { Barrier }\end{array}$} & Fuel Reliability & $<50 \%$ TS limit & $\geq 50 \%$ TS limit & $\geq 100 \%$ TS limit & No Threshold \\
\hline & & Reactor Coolant Leakage & $<50 \%$ TS limit & $\geq 50 \%$ TS limit & $\geq 100 \%$ TS limit & No Threshold \\
\hline & & Containment Reliability & $\geq 90 \%$ & $<90 \%$ & $<60 \%$ & No Threshold \\
\hline & & Emergency Preparedness & $\geq 90 \%$ & $<90 \%$ & $<60 \%$ & No Threshold \\
\hline & \multirow{5}{*}{$\begin{array}{l}\text { Mitigating } \\
\text { System }\end{array}$} & MSPI - EAC & $<1 \mathrm{E}-6$ and $<\mathrm{PL}^{20}$ & $\geq 1 \mathrm{E}-6$ or $\geq \mathrm{PL}$ & $\geq 1 \mathrm{E}-5$ & $\geq 1 \mathrm{E}-4$ \\
\hline & & MSPI - HPSI & $<1 \mathrm{E}-6$ and $<\mathrm{PL}$ & $\geq 1 \mathrm{E}-6$ or $\geq \mathrm{PL}$ & $\geq 1 \mathrm{E}-5$ & $\geq 1 \mathrm{E}-4$ \\
\hline & & MSPI - AFW & $<1 \mathrm{E}-6$ and $<\mathrm{PL}$ & $\geq 1 \mathrm{E}-6$ or $\geq \mathrm{PL}$ & $\geq 1 \mathrm{E}-5$ & $\geq 1 \mathrm{E}-4$ \\
\hline & & MSPI - RHR & $<1 \mathrm{E}-6$ and $<\mathrm{PL}$ & $\geq 1 \mathrm{E}-6$ or $\geq \mathrm{PL}$ & $\geq 1 \mathrm{E}-5$ & $\geq 1 \mathrm{E}-4$ \\
\hline & & MSPI - CCW/SWS & $<1 \mathrm{E}-6$ and $<\mathrm{PL}$ & $\geq 1 \mathrm{E}-6$ or $\geq \mathrm{PL}$ & $\geq 1 \mathrm{E}-5$ & $\geq 1 \mathrm{E}-4$ \\
\hline
\end{tabular}

assumptions, and so on.

- The problem of 'insensitive indicators' can be solved to some degree using the supplemental performance threshold 'backstop' to limit the total number of component failures.

Secondly, the thresholds of the existing KINS SPIs were evaluated considering the risk and regulatory response in the graded inspection program. The PSA results were used to evaluate the thresholds of the URS, and qualitative discussions were presented for the other SPIs.

Finally, the PIs and their thresholds for use in the graded regulation program for Korean NPPs are proposed as presented in Table 35. They include the USwC and MSPI, and the modified performance thresholds. The BRIIE is not included in Table 35 because it is recommended that the BRIIE be used as an industry level initiating event PI.

Although some PIs and their thresholds are proposed in this paper, the following items need to be studied further to finalize and implement the KINS SPI for use in the graded regulation program.

- The thresholds of the BRIIE are not limited to the prediction limits based on the performance, but also include the risk thresholds based on the conditional core damage probability (CCDP). Because only the prediction limits are addressed in this paper, an additional study is required to consider the risk thresholds for the implementation of the BRIIE.
- An extensive comparison of the Birnbaums between the PSA results of each reactor type is needed, especially for basic events that are used in the MSPI calculation. Moreover, the baseline unreliability and unavailability in equations (4) and (5) and the backstop in equations (7) and (8) must be determined based on Korea-specific component reliability and availability data for the implementation of MSPI in Korea.

- The safety system functional failures (SSFFs) PIs of ROP in the USNRC are not addressed in this paper. The definition of the SSFF is the number of events or conditions that prevented, or could have prevented, the fulfillment of the safety function of the structures or systems in the previous four quarters [2]. The primary data source for the SSFFs in the USNRC is the licensee event report system based on 10CFR50.73 [21]. Because the existing regulations on reporting in Korea [22] do not require the SSFF data, the applicable threshold for SSFFs that is determined by the historical performance cannot be established at present. Therefore, the SSFFs PI is not included in Table 35. However, if the regulation on reporting in Korea is modified to include SSFFs in the future, the SSFFs PI should be included in Table 35 as a PI for graded regulation.

\footnotetext{
${ }^{20}$ PL: Performance Limit.
} 
- Because the PIs in the nuclear safety area have only been addressed in this study, the PIs in the radiation safety area should also be evaluated in the future to finalize the KINS SPI system for the graded regulation program.

\section{Acknowledgments}

This work has been performed under the Nuclear R\&D Program sponsored by the Ministry of Education, Science and Technology, Korea.

\section{ACRONYMS}

\begin{tabular}{|c|c|}
\hline $\mathrm{AAC}$ & $\begin{array}{l}=\text { Alternate AC (Alternating Current) Power } \\
\text { System }\end{array}$ \\
\hline AFW & $=$ Auxiliary Feedwater System \\
\hline $\mathrm{AOV}$ & $=$ Air Operated Valve \\
\hline BRIIE & $=$ Baseline Risk Index for Initiating Events \\
\hline CANDU & $=$ Canada Deuterium Uranium \\
\hline $\mathrm{CCF}$ & $=$ Common Cause Failure \\
\hline $\mathrm{CCW}$ & $=$ Component Cooling Water System \\
\hline $\mathrm{CDF}$ & $=$ Core Damage Frequency \\
\hline $\mathrm{CI}$ & $=$ Containment Integrity \\
\hline CVC & $=$ Chemical and Volume Control System \\
\hline EAC & $=$ Emergency AC Power System \\
\hline EDG & $=$ Emergency Diesel Generator \\
\hline EOP & $=$ Emergency Operating Procedure \\
\hline EP & $=$ Emergency Preparedness \\
\hline FR & $=$ Fuel Reliability \\
\hline HPSI & $=$ High Pressure Injection System \\
\hline HRS & $=$ Heat Removal System \\
\hline ISPA & $=$ Integrated Safety Performance Assessment \\
\hline ITP & $=$ Industry Trend Program \\
\hline KINS & $=$ Korea Institute of Nuclear Safety \\
\hline LOAC & $=$ Loss of Vital AC (Alternating Current) Bus \\
\hline LOCHS & $=$ Loss of Condenser Heat Sink \\
\hline LODC & $=$ Loss of Vital DC (Direct Current) Bus \\
\hline LOIA & $=$ Loss of Instrument Air \\
\hline LOMFW & $=$ Loss of Main Feedwater \\
\hline LONHR & $=$ Loss of Normal Heat Removal \\
\hline LOOP & $=$ Loss of Offsite Power \\
\hline MDP & $=$ Motor Driven Pump \\
\hline MSPI & $=$ Mitigating System Performance Index \\
\hline NPPs & $=$ Nuclear Power Plants \\
\hline OPR & $=$ Optimized Power Reactor \\
\hline PI & $=$ Performance Indicator \\
\hline PL & $=$ Performance Limit \\
\hline PSA & $=$ Probabilistic Safety Assessment \\
\hline PWR & $=$ Pressurized Water Reactor \\
\hline RCL & $=$ Reactor Coolant Leakage \\
\hline RHR & $=$ Residual Heat Removal System \\
\hline ROP & $=$ Reactor Oversight Process \\
\hline SGTR & $=$ Steam Generator Tube Rupture \\
\hline SLOCA & $=$ Small LOCA \\
\hline SORV & $=$ Stuck Open SRV \\
\hline SPI & $=$ Safety Performance Indicator \\
\hline
\end{tabular}

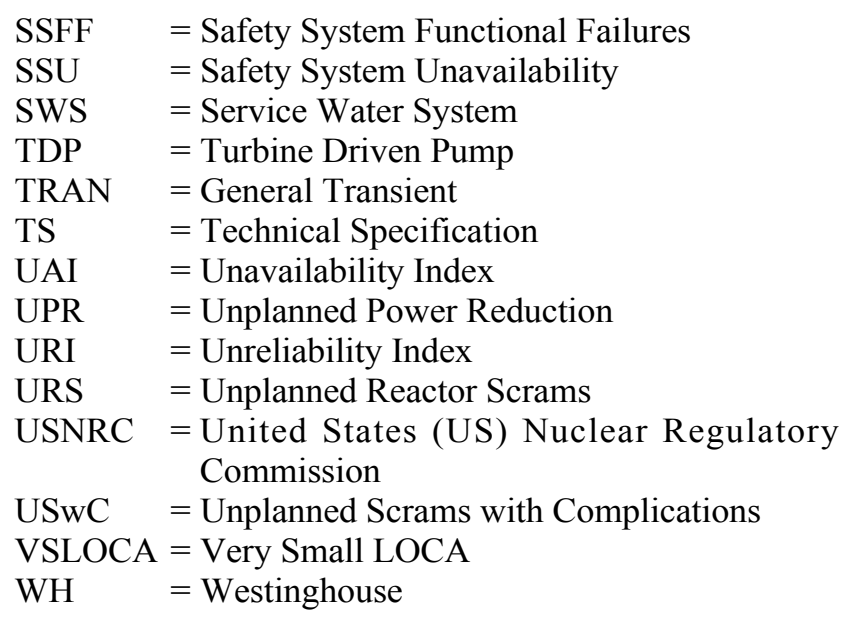

\section{REFERENCES}

[1 ] NEA, "Joint CSNI-CNRA Report on Regulatory Uses of Safety Performance Indicators", NEA/CNRA/R(2006)

[2] NEI, "Regulatory Assessment Performance Indicator Guideline", NEI 99-02, Rev. 5 (2007)

[ 3 ] D.H.Lee et al., "Assessment of Nuclear Safety Performance Indicators (in Korean)”, KINS-AR/802, KINS, (2008).

[4 ] USNRC, "Reactor Oversight Process", NUREG-1649. Rev.4, (2006)

[5] D.W.Chung et al., "Use of PSA and Safety Performance Assessment in Improving Regulatory Inspection System", PSAM-9, Hong Kong (2008)

[6] USNRC, "Independent Verification of the Mitigating Systems Performance Index (MSPI) Results for the Pilot Plants", NUREG-1816, (2005)

[ 7 ] Y.S.Lee et al., "Development of Methodologies for RiskInformed Approaches to Safety Performance of NPPs", KINS/HR-865, (2008)

[ 8 ] ROPWG Subgroup, "Unplanned Scrams with Complications, 2006”, Complicated Scrams Task Group Report, (2006)

[9] USNRC, "Baseline Risk Index for Initiating Events (BRIIE)", NUREG/CR-6932, (2007)

[10] J.H.Park et al., "Transient Initiating Event Analysis for Nuclear Power Plants in Korea", Transactions of the Korean Nuclear Society Spring Meeting (2007)

[11] Glen Masters, "Failures to White Industry Operating Experience", Presentation Material in MSPI Workshop, San Francisco, Aug. 11-13, (2008)

[12] USNRC, "Standardized Plant Analysis Risk Model and Other Probabilistic Risk Assessment Lessons Learned from Mitigating Systems Performance Index Development and Implementation", Enclosure 3 in SECY 06-0208, (2006)

[13] D.I.Kang et al., "Development on the Application Technology of Risk-Based Performance Indicator for Domestic NPPs (in Korean)", KINS/HR-660, (2005)

[14] J.H.Park et al., "Evaluation of Loss of Offsite Power events at Nuclear Power Plants in Korea", Transactions of the Korean Nuclear Society Autumn Meeting Busan, Korea, October 27-28, (2005)

[15] USNRC, "Recommendations for Reactor Oversight Process Improvements", SECY-99-007, NRC (1999) 
[16] USNRC, “An Approach for Using Probabilistic Risk Assessment in Risk-Informed Decisions on Plant-Specific Changes to the Licensing Basis", RG 1.174, (1998)

[17] USNRC, "Elevation of the Core Damage Frequency Objective to a Fundamental Commission Safety Goal", SECY-97-208, (2007)

[18] KINS, "Technical Guideline for Risk-Informed Decisions on Plant-Specific Changes to the Licensing Basis of Nuclear Facilities", KINS-GT-N24

[19] KINS/RR-588, Study for Establishment of Draft Safety
Goal and Its Following Action Items, 2008

[20] D.I. Kang et al., "Determination of Performance Indicator Thresholds Based on Typical PSA Results", Journal of the Korean Nuclear Society, Vol 36, No 6, pp.485-496, (2004)

[21] USNRC, “Licensee event report system", 10CFR50.73

[22] MEST, "Regulation on Reporting and Public Announcement of Accidents and Incidents for Nuclear Power Utilization Facilities", Notice of the Ministry of Education, Science and Technology Applicable to Nuclear Installations, 2009-24 